\title{
YIELD AND QUALITY OF BLACK CUMIN (Nigella sativa L.) ACCORDING TO LEONARDITE AND NITROGEN DOSES
}

\author{
ÖZYAZICI, G. \\ Department of Field Crops, Faculty of Agriculture, Siirt University, Siirt, Turkey \\ e-mail: gulenozyazici@ siirt.edu.tr; phone: +90-533-221-8208 \\ (Received $29^{\text {th }}$ Feb 2020; accepted $9^{\text {th }}$ Jul 2020)
}

\begin{abstract}
This study aimed to reveal the effect of different levels of leonardite and nitrogen fertilizer applied to the soil on seed yield and some quality parameters of black cumin (Nigella sativa L.). The study was carried out in the Southeastern Anatolia Region of Turkey between the years 2016-2018. In the study, 4 different doses of leonardite and nitrogen fertilizer were administered. In the study, the highest plant height and number of branches were found in $\mathrm{L}_{2} \mathrm{~N}_{90}$, the highest number of capsules was found in $\mathrm{L}_{2} \mathrm{~N}_{60}$, and the highest number of seed per capsule was found in $\mathrm{L}_{2} \mathrm{~N}_{60}$ and $\mathrm{L}_{3} \mathrm{~N}_{60}$. As a result of the study, the highest seed yield was obtained from $\mathrm{L}_{2}$ and $\mathrm{L}_{3}$ doses of leonardite and from $\mathrm{N}_{60}$ dose of nitrogen. It was determined that the fixed oil ratio, essential oil ratio contained in the black cumin seeds, and essential oil components parallel with the increase in leonardite and nitrogen doses. It was concluded that leonardite, a soil conditioner, could be used in black cumin cultivation under semi-arid climate conditions and that $2000 \mathrm{~kg} \mathrm{ha}^{-1}$ leonardite and $60 \mathrm{~kg} \mathrm{ha}^{-1}$ nitrogen could be applied to improve the yield and quality of black cumin.
\end{abstract}

Keywords: soil conditioner, thymoquinone, seed yield, Nigella sativa, essential oil, fixed oil

\section{Introduction}

The blackcumin is a annual herbaceous plant from the Ranunculaceae family. It is distributed over a wide area from southern and eastern shores of Indian continent to mediterranan basin (Egypt and Turkey) (Seyyedi et al., 2015; Kılıç and Arabacı, 2016). It has 12 species distributed in Turkey. Nigella sativa and Nigella damascena species are commonly cultivated (Baydar, 2013). One of the most famous books in the history of medicine by İbn-i Sina, the author of "El Kanun Fi"e ttıb", states that black cumin stimulates metabolism, prevents drowsiness and fatigue, regulates body energy and restores vitality lost by disease (Nasr, 2008). The seeds of black cumin have high economic value and contain fixed oil, essential oil, protein and carbohydrates. It also contains nigellidin, nigellisin and nigellimin in alkaloids in seeds (Baydar, 2013).

Black cumin is an important spice species and have high production especially in East and Southeast Asia. There is no specific report of production area and amount for black cumin, but for spice production India, China and Turkey leads world production (Dessie et al., 2020).

Humic acids, which are among the most important components of humic substances, are heterogeneous natural resources with high molecular weight and colors varying from yellow to black (Akınc1, 2011), and they have significant benefits in terms of both improving soil properties and agricultural production such as increasing the cation exchange capacity of the soils and neutralizing the $\mathrm{pH}$ of the soil (Stevenson, 1994), making plant nutrients bound to soil colloids available (Y1lmaz, 2007), slowing down the evaporation of water in the soil (Akıncı, 2011; Sesveren and Taş, 2018), improving soil microflora (Larcher, 2003; Calvo et al., 2014; Li et al., 2019), improving plant growth, yield, and quality (Sharif et al., 2002; Esringü et al., 2015; Selladurai and Purakayastha, 2016; Çöl and Akınerdem, 2017; Ahmad et al., 2018), and increasing the 
uptake of mineral elements in plants (Mackowiak et al., 2001; Eyheraguibel et al., 2008; Khaled and Fawy, 2011). Leonardite constitutes the raw material of humic acids that are classified as soil conditioners (Pekcan et al., 2018). Leonardite, which is a sedimentary rock formed by the changes of plant and animal remains during a period of millions of years (Pekcan et al., 2018), is an all-natural organic material that has not reached the level of coal (Sesveren and Taş, 2018). The use of materials such as leonardite to increase the organic matter content of the soil, especially in agricultural soils containing low organic matter with an intense polyculture production pattern, takes an important place nowadays.

It was reported that humic acid applications in Brassica napus ssp. oleifera L. plant had positive effects on plant height, the number of sub-branches attached to the main stem, the number of capsules in the main stem, the number of seeds per capsule, thousand grain weight, seed yield, oil ratio, and oil yield properties (Gürsoy and Kolsarıc1, 2017), that better tuber yields were obtained with humic acid and fulvic acid applications in the potato plant especially in dry and cool periods (Wadas and Dziugieł, 2019), and that potassium fertilizer and humic acid doses applied in increasing amounts in Helianthus annuus L. plant had significant effects on the yield and yield components and mineral content of the plant (Yağmur and Okur, 2017). Similarly, it was determined that the tuber yield in potato (Şanlı et al., 2013), wheat grain yield (Kolay et al., 2016), rye dry matter yield (Adiloğlu et al., 2017) increased in parallel with the increase in leonardite doses.

Obtaining high yields and quality products in agricultural production depends on giving the nutrients needed by the plant to plants in the appropriate period and dose, along with the accurate and timely implementation of many other cultural practices. In this sense, nitrogen $(\mathrm{N})$ is the primary element among nutrients that are absolutely essential for many cultivated plants. The unconscious and excessive use of fertilizers, which are the most important inputs of agricultural activities, is shown to be one of the most important causes of soil pollution nowadays, and high doses of fertilizer applications also lead to toxic accumulation in plants, the inhibition of the intake of some other nutrients, and of course, economic losses. Therefore, the determination of nutrient needs of cultivated plants in different ecologies and the preparation of fertilization programs according to the soil analysis results constitute the most important branches of sustainable agriculture techniques.

Moreover, it is necessary to carry out cultural application techniques that minimize agricultural inputs such as fertilizer. For this purpose, it is essential to use soil conditioners such as leonardite in plant production, especially in agricultural soils where soil organic matter is low and, consequently, the intake of nutrients is prevented, and to reveal the interaction with other nutrients, and to show its effects on product yield and quality. In this study, it was aimed to reveal the effect of leonardite and nitrogen fertilizer applied to the soil at different levels on seed yield and some quality parameters of black cumin.

\section{Materials and methods}

The study was carried out between 2016-2018 under the ecological conditions of Siirt province located in the Southeastern Anatolia Region of Turkey, which has a semiarid climate. Siirt is located at $37^{\circ} 58^{\prime} 7.37^{\prime \prime} \mathrm{N}$ and $41^{\circ} 51^{\prime} 3.87^{\prime \prime}$ E coordinates with $894 \mathrm{~m}$ altitude (Figure 1, Figure 2). 


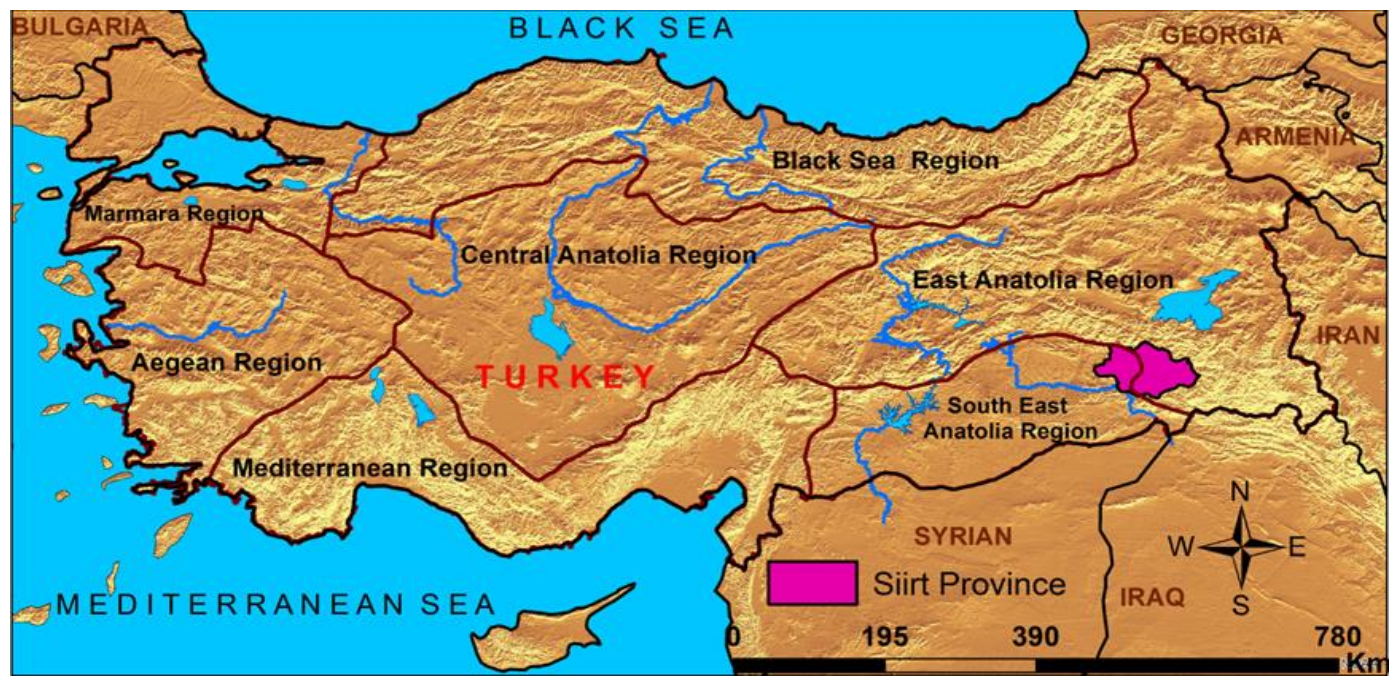

Figure 1. Location of the study area in Turkey
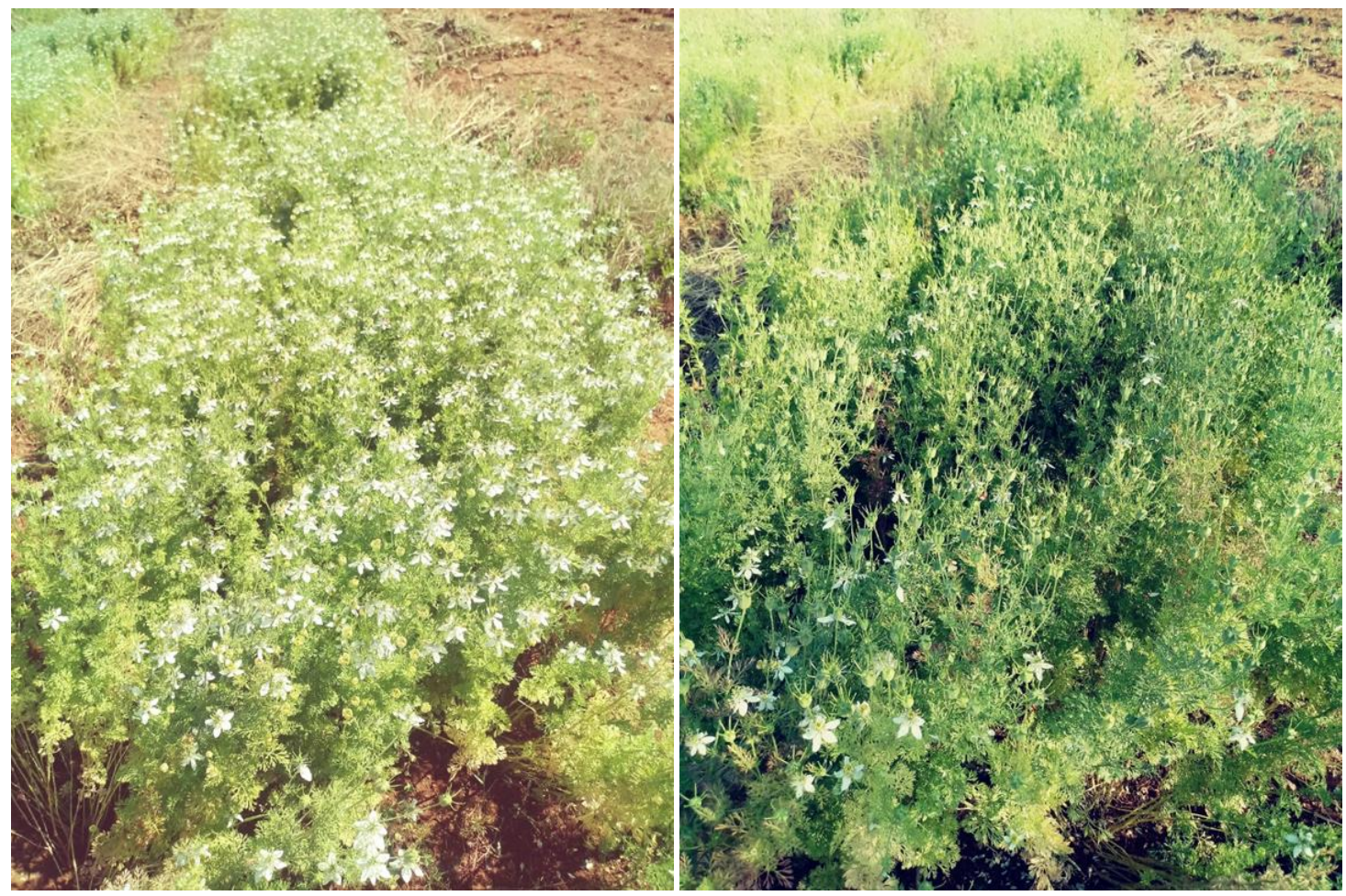

Figure 2. A photo of the research area

In the second year of the study, less precipitation $(522.8 \mathrm{~mm})$ occurred in comparison with the first year $(574.2 \mathrm{~mm})$, while the long-term annual precipitation was $634.1 \mathrm{~mm}$. While the highest precipitation occurred in March and April during the 2016-2017 vegetation period, the highest precipitation was recorded in May during the 2017-2018 vegetation period (Table 1). The mean temperature during the study years and the longterm mean temperature (38 years) were $11.2{ }^{\circ} \mathrm{C}, 13.8{ }^{\circ} \mathrm{C}$, and $11.4{ }^{\circ} \mathrm{C}$, respectively (Table 1) (Anonymous, 2018). 
Table 1. Climate characteristics of trial area

\begin{tabular}{c|c|ccccccccc}
\hline \multirow{2}{*}{$\begin{array}{c}\text { Climate } \\
\text { parameters }\end{array}$} & $\begin{array}{c}\text { Research } \\
\text { years }\end{array}$ & \multicolumn{10}{|c}{ Months } \\
\cline { 3 - 10 } & Nov & Dec & Jan & Feb & Mar & Apr & May & June & Mean/Sum \\
\hline $\begin{array}{c}\text { Average } \\
\text { temparature }\end{array}$ & $2016-2017$ & 10.4 & 3.3 & 3.0 & 2.7 & 9.6 & 14.0 & 19.5 & 26.9 & 11.2 \\
$\left({ }^{\circ} \mathrm{C}\right)$ & $2017-2018$ & 11.2 & 8.0 & 5.7 & 8.2 & 13.7 & 16.8 & 19.8 & 27.4 & 13.8 \\
\hline Long term & $*$ & 10.3 & 4.9 & 3.0 & 4.5 & 8.8 & 14.3 & 19.5 & 26.2 & 11.4 \\
\hline $\begin{array}{c}\text { Monthly } \\
\text { precipitation }\end{array}$ & $2016-2017$ & 55.4 & 116.6 & 46.4 & 29.2 & 119.2 & 132.8 & 74.6 & 0.0 & 574.2 \\
$(\mathrm{~mm})$ & $2017-2018$ & 86.0 & 47.4 & 56.4 & 74.2 & 47.6 & 61.6 & 139.6 & 10.0 & 522.8 \\
\hline
\end{tabular}

*: 1980-2018

In the study, some physical and chemical analysis results of the soils taken before establishing the field trial were presented in Table 2. In the first year (2016-2017), the trial area soils were loamy textured, and they were clay-loam textured in the second year (2017-2018); both trial area soils were slightly alkaline, salt-free, their lime content was "medium calcareous," the organic matter content was "low," and the available potassium (K) content was "sufficient." The available P content of the soils in the first year was determined to be "very little," and the available P content of the soils in the second year was determined to be "low" (Table 2).

Table 2. Some physical and chemical properties of the study area soils $(0-20 \mathrm{~cm})^{*}$

\begin{tabular}{c|cc}
\hline \multirow{2}{*}{ Properties } & \multicolumn{2}{c}{ Value } \\
\cline { 2 - 3 } & $\mathbf{2 0 1 6 - 2 0 1 7}$ & $\mathbf{2 0 1 7 - 2 0 1 8}$ \\
Clay, \% & 47.56 & 34.16 \\
Silt, \% & 12.11 & 26.00 \\
Sand, \% & 40.33 & 39.84 \\
pH & 7.72 & 7.53 \\
Electrical conductivity (EC), $\mathrm{mS} \mathrm{cm}^{-1}$ & 0.363 & 0.150 \\
Lime $\left(\mathrm{CaCO}_{3}\right), \%$ & 12.0 & 8.2 \\
Organic matter, \% & 1.31 & 1.78 \\
Available phosphorus, $\mathrm{kg} \mathrm{P}_{2} \mathrm{O}_{5} \mathrm{ha}^{-1}$ & 24 & 49 \\
Available potassium, $\mathrm{kg} \mathrm{K}_{2} \mathrm{O} \mathrm{ha}^{-1}$ & 1430 & 1250 \\
\hline
\end{tabular}

*: Analyses were carried out in Siirt University, Science and Technology Application and Research Center Laboratory

As the plant material in the study, black cumin ( N. sativa L.) seeds, belonging to the "Isparta population" and seeded locally in the Mediterranean Region of Turkey, were used.

In this study, the field trial was established as three replications in randomized blocks according to the factorial trial design. In the study, 4 different leonardite doses $\left(\mathrm{L}_{0}=0\right.$, $\mathrm{L}_{1}=1000, \mathrm{~L}_{2}=2000$, and $\mathrm{L}_{3}=3000 \mathrm{~kg} \mathrm{ha}^{-1}$ leonardite) and 4 different nitrogen doses $\left(\mathrm{N}_{0}=0, \mathrm{~N}_{30}=30, \mathrm{~N}_{60}=60\right.$, and $\left.\mathrm{N}_{90}=90 \mathrm{~kg} \mathrm{~N} \mathrm{ha}^{-1}\right)$ constituted the subject of the study. "Leonagro" was used as the source of leonardite, and urea $(46 \% \mathrm{~N})$ was used as the source of nitrogen fertilizer. The content of the leonardite material is given in Table 3. According to the research subjects, both fertilizer forms were mixed by applying them to the soil before seeding. 
Table 3. Some properties of leonardite using the trial

\begin{tabular}{c|c|c}
\hline $\mathbf{p H}$ & Humic + Fulvic acid (\%) & Organic Matter (\%) \\
\hline $6-8$ & 40 & 40 \\
\hline
\end{tabular}

The seeding process was performed manually on 15 November 2016 in the first year and on 17 November 2017 in the second year on the grooves opened with the help of a marker. In the study, row distance was $30 \mathrm{~cm}$ and parcel distance was $100 \mathrm{~cm}$. Each parcel constituted from four rows, while length and width of the parcels were 3 meter by 1.2 meter each with a total area of $3.6 \mathrm{~m}^{2}$ per parcel. Sowing norm was $30 \mathrm{~kg} \mathrm{ha}^{-1}$, and sowing was done manually in rows opened with the help of a marker.Weed control was performed mechanically by hand several times in both years. At the harvest, two border rows and $50 \mathrm{~cm}$ from each side were excluded to eliminate border effects.

Plant height, number of branches, number of capsules, number of seed per capsule, seed weight were determined in 10 plants randomly selected in each parcel before harvest. The harvest was carried in the entire plot area, excluding borders in the first week of July in both years. The harvested plants were dried in the shade for 3-4 days, and seed yields were calculated per decare. Thousand seed weight, fixed oil and essential oil analysis were performed. For the fixed oil percentage grinded samples were dried at $105{ }^{\circ} \mathrm{C}$ for 3 hours and $10 \mathrm{~g}$ sample was fed into a Soxhlet apparatus (SOXTHERM $\left.{ }^{\circledR} 2000\right)$. The extraction was performed on a water bath at $60{ }^{\circ} \mathrm{C}$ for $4 \mathrm{~h}$ with $200 \mathrm{~mL}$ petroleum ether. For the essential analysis percentage; seeds dried at $35^{\circ} \mathrm{C}$ in room were crushed bu using grinder. Distillation process was carried out using the Clevenger apparatus. Distilled water $(250 \mathrm{ml})$ was used, and $25 \mathrm{~g}$ crushed fruit were watered with $250 \mathrm{ml}$ distilled water (1:10). Distillation lasted for approximately $5 \mathrm{~h}$ at boiling point. The essential oil collected at the end of distillation was measured in $\mathrm{mL}$ and calculated as \% (v/w). The essential oil components of black cumin seed were determined using Headspace GC-MS. Crushed black seed samples was taken $1 \mathrm{~g}$ and placed in a $25 \mathrm{~mL}$ Chromacol Headspace vial. The vial was heated in a Triplus RSH Headspace oven for 90 minutes at $120^{\circ} \mathrm{C}$. The heated Headspace was sent from the vial to the GC-MS with an injection volume of $2.5 \mathrm{~mL}$. The analysis was carried out in a Trace 1310 gas chromatograph equipped with an ISQ single quadrupole mass spectrometer (Thermo Fisher Scicentific, Austin, TX). The procedure was set to an initial temperament $60{ }^{\circ} \mathrm{C}$ for $10 \mathrm{~min}$, then ramp at $1{ }^{\circ} \mathrm{C} / \mathrm{min}$ to $140{ }^{\circ} \mathrm{C}, 1 \mathrm{~min}$ in $140{ }^{\circ} \mathrm{C}$, then ramp at $15^{\circ} \mathrm{C} / \mathrm{min}$ to $230{ }^{\circ} \mathrm{C}$ and finally $5 \mathrm{~min}$ in $230^{\circ} \mathrm{C}$. The ion source and detector temperature was $220^{\circ} \mathrm{C}$ and $220{ }^{\circ} \mathrm{C}$, respectively. Separation of sample was performed on a Thermo TG-WAXMS GC column ( $60 \mathrm{~m}$ x $0.25 \mathrm{~mm}$ ID x $0.25 \mu \mathrm{m}$ ) using helium as carrier gas at $1.2 \mathrm{ml} / \mathrm{min}$. Mass spectral scan range was set at the rate of 55-550 (amu). Peak identification was conducted by comparison of the known components stored in the NIST Demo, Wiley7, Wiley9, redlip, mainlip, WinRI.

The data were analyzed by JMP statistical software. A homogeneity test was applied to the data obtained from the study. According to the results of the homogeneity test, they were subjected to combined variance analysis (ANOVA) according to the factorial trial design in randomized blocks. According to the F-test results, differences between the groups were determined by the LSD multiple comparison test (Yurtsever, 1984). 


\section{Results and discussion}

\section{Plant height}

According to the results of a two-year study, the effects of leonardite and nitrogen fertilizer doses on the plant height of black cumin were found to be statistically significant at a level of $\mathrm{p}<0.01$ (Table 4).

Table 4. Means of yield components at different leonardite and nitrogen doses in black cumin

\begin{tabular}{|c|c|c|c|c|c|c|c|c|c|c|}
\hline \multirow{2}{*}{$\begin{array}{c}L \\
\text { doses }\end{array}$} & \multirow{2}{*}{$\begin{array}{c}\mathrm{N} \\
\text { doses }\end{array}$} & \multicolumn{3}{|c|}{$\begin{array}{c}\text { Plant height } \\
(\mathbf{c m})\end{array}$} & \multicolumn{3}{|c|}{$\begin{array}{c}\text { Number of branches } \\
\text { (unit/plant) }\end{array}$} & \multicolumn{3}{|c|}{$\begin{array}{c}\text { Number of capsules } \\
\text { (unit/plant) }\end{array}$} \\
\hline & & 2017 & 2018 & Mean* & 2017 & 2018 & Mean* & 2017 & 2018 & Mean* \\
\hline \multirow{4}{*}{$\mathrm{L}_{0}$} & $\mathrm{~N}_{0}$ & 49.87 & 50.87 & $50.37 \mathrm{~g}$ & 3.47 & 3.60 & $3.53 \mathrm{~g}$ & 4.63 & 4.77 & $4.70 \mathrm{~h}$ \\
\hline & $\mathrm{N}_{30}$ & 53.27 & 56.20 & $54.73 \mathrm{efg}$ & 3.60 & 3.70 & $3.65 \mathrm{~d}-\mathrm{g}$ & 5.47 & 6.07 & $5.77 \mathrm{~cd}$ \\
\hline & $\mathrm{N}_{60}$ & 61.70 & 64.20 & $62.95 \mathrm{bc}$ & 3.80 & 3.83 & $3.82 \mathrm{ab}$ & 6.57 & 7.13 & $6.85 \mathrm{a}$ \\
\hline & $\mathrm{N}_{90}$ & 59.23 & 65.97 & $62.60 \mathrm{bc}$ & 3.80 & 3.83 & $3.82 \mathrm{ab}$ & 5.07 & 5.57 & $5.32 \mathrm{~d}-\mathrm{g}$ \\
\hline \multicolumn{2}{|c|}{$\mathrm{L}_{0}$ Mean } & 56.02 & 59.31 & $57.66 \mathrm{C}$ & 3.67 & 3.74 & 3.70 & 5.43 & 5.88 & 5.66 \\
\hline \multirow{4}{*}{$\mathrm{L}_{1}$} & $\mathrm{~N}_{0}$ & 51.50 & 54.09 & $52.80 \mathrm{~g}$ & 3.63 & 3.73 & $3.68 b-f$ & 4.93 & 5.27 & $5.10 \mathrm{fgh}$ \\
\hline & $\mathrm{N}_{30}$ & 61.13 & 62.97 & $62.05 \mathrm{bc}$ & 3.57 & 3.63 & $3.60 \mathrm{fg}$ & 4.97 & 5.30 & $5.13 \mathrm{e}-\mathrm{h}$ \\
\hline & $\mathrm{N}_{60}$ & 62.80 & 61.25 & $62.02 \mathrm{bc}$ & 3.80 & 3.80 & $3.80 \mathrm{bc}$ & 6.27 & 5.67 & $5.97 \mathrm{bc}$ \\
\hline & $\mathrm{N}_{90}$ & 58.53 & 58.80 & $58.67 \mathrm{cde}$ & 3.70 & 3.90 & $3.80 \mathrm{bc}$ & 5.33 & 6.07 & $5.70 \mathrm{cde}$ \\
\hline \multicolumn{2}{|c|}{$\mathrm{L}_{1}$ Mean } & 58.49 & 59.28 & $58.88 \mathrm{BC}$ & 3.68 & 3.77 & 3.72 & 5.38 & 5.58 & 5.48 \\
\hline \multirow{4}{*}{$\mathrm{L}_{2}$} & $\mathrm{~N}_{0}$ & 52.73 & 55.71 & $54.22 \mathrm{fg}$ & 3.70 & 3.70 & $3.70 b-f$ & 4.87 & 5.00 & $4.93 \mathrm{gh}$ \\
\hline & $\mathrm{N}_{30}$ & 51.13 & 56.89 & $54.02 \mathrm{fg}$ & 3.47 & 3.60 & $3.53 \mathrm{~g}$ & 4.70 & 4.80 & $4.75 \mathrm{gh}$ \\
\hline & $\mathrm{N}_{60}$ & 64.46 & 62.31 & $63.39 \mathrm{~b}$ & 3.53 & 3.70 & $3.62 \mathrm{efg}$ & 7.40 & 6.43 & $6.92 \mathrm{a}$ \\
\hline & $\mathrm{N}_{90}$ & 65.30 & 71.47 & $68.38 \mathrm{a}$ & 3.97 & 3.93 & $3.95 \mathrm{a}$ & 5.40 & 5.90 & $5.65 \mathrm{c}-\mathrm{f}$ \\
\hline \multicolumn{2}{|c|}{$\mathrm{L}_{2}$ Mean } & 58.41 & 61.60 & $60.00 \mathrm{AB}$ & 3.67 & 3.73 & 3.70 & 5.59 & 5.53 & 5.56 \\
\hline \multirow{4}{*}{$\mathrm{L}_{3}$} & $\mathrm{~N}_{0}$ & 56.03 & 59.13 & $57.58 \mathrm{def}$ & 3.77 & 3.80 & $3.78 \mathrm{bcd}$ & 4.92 & 4.95 & $4.94 \mathrm{gh}$ \\
\hline & $\mathrm{N}_{30}$ & 61.30 & 62.56 & $61.93 \mathrm{bcd}$ & 3.70 & 3.80 & $3.75 \mathrm{~b}-\mathrm{e}$ & 5.60 & 5.63 & $5.62 \mathrm{c}-\mathrm{f}$ \\
\hline & $\mathrm{N}_{60}$ & 58.40 & 63.87 & $61.13 \mathrm{bcd}$ & 3.70 & 3.80 & $3.75 \mathrm{~b}-\mathrm{e}$ & 6.48 & 6.53 & $6.51 \mathrm{ab}$ \\
\hline & $\mathrm{N}_{90}$ & 62.50 & 66.97 & $64.74 \mathrm{ab}$ & 3.67 & 3.67 & $3.67 \mathrm{c}-\mathrm{g}$ & 5.83 & 5.88 & $5.86 \mathrm{~cd}$ \\
\hline \multicolumn{2}{|c|}{$\mathrm{L}_{3}$ Mean } & 59.56 & 63.13 & $61.35 \mathrm{~A}$ & 3.71 & 3.77 & 3.74 & 5.71 & 5.75 & 5.73 \\
\hline \multicolumn{11}{|c|}{ N Mean } \\
\hline \multicolumn{2}{|c|}{$\mathrm{N}_{0}$} & 52.53 & 54.95 & $53.74 \mathrm{c}$ & 3.64 & 3.71 & $3.68 \mathrm{~b}$ & 4.84 & 4.99 & $4.92 \mathrm{~d}$ \\
\hline \multicolumn{2}{|c|}{$\mathrm{N}_{30}$} & 56.71 & 59.66 & $58.18 \mathrm{~b}$ & 3.58 & 3.68 & $3.63 \mathrm{~b}$ & 5.19 & 5.45 & $5.32 \mathrm{c}$ \\
\hline \multicolumn{2}{|c|}{$\mathrm{N}_{60}$} & 61.84 & 62.91 & $62.37 \mathrm{a}$ & 3.71 & 3.78 & $3.75 \mathrm{a}$ & 6.68 & 6.44 & $6.56 \mathrm{a}$ \\
\hline \multicolumn{2}{|c|}{$\mathrm{N}_{90}$} & 61.39 & 65.80 & $63.60 \mathrm{a}$ & 3.78 & 3.83 & $3.81 \mathrm{a}$ & 5.41 & 5.86 & $5.64 \mathrm{~b}$ \\
\hline \multicolumn{2}{|c|}{ Means } & $58.12 \mathrm{~B}$ & $60.82 \mathrm{~A}$ & & $3.68 \mathrm{~B}$ & $3.75 \mathrm{~A}$ & & 5.53 & 5.69 & \\
\hline \multicolumn{2}{|c|}{ CV (\%) } & & 6.40 & & & 3.23 & & & 8.99 & \\
\hline \multicolumn{2}{|c|}{ Year $(\mathrm{Y})$} & & ** & & & $* *$ & & & $\mathrm{~ns}$ & \\
\hline \multicolumn{2}{|c|}{ Leonardite $(\mathrm{L})$} & & $* *$ & & & ns & & & $\mathrm{ns}$ & \\
\hline \multicolumn{2}{|c|}{ Nitrogen $(\mathrm{N})$} & & $* *$ & & & ** & & & $* *$ & \\
\hline \multicolumn{2}{|c|}{$\mathrm{LxN}$} & & $* *$ & & & ** & & & $* *$ & \\
\hline \multicolumn{2}{|c|}{ LxNxY } & & $\mathrm{ns}$ & & & ns & & & $\mathrm{ns}$ & \\
\hline
\end{tabular}

$\mathrm{L}_{0}=$ Control, $\mathrm{L}_{1}=1000 \mathrm{~kg} \mathrm{ha}^{-1}$ leonardite, $\mathrm{L}_{2}=2000 \mathrm{~kg} \mathrm{ha}^{-1}$ leonardite, $\mathrm{L}_{3}=3000 \mathrm{~kg} \mathrm{ha}^{-1}$ leonardite, $\mathrm{N}_{0}=$ Control, $\mathrm{N}_{30}=30 \mathrm{~kg} \mathrm{ha}^{-1}$ nitrogen, $\mathrm{N}_{60}=60 \mathrm{~kg} \mathrm{ha}^{-1}$ nitrogen, $\mathrm{N}_{90}=90 \mathrm{~kg} \mathrm{ha}^{-1}$ nitrogen, $*$ : The difference between the means indicated by the same letter in the same column and group is not significant, CV: Coefficient of variation, ns: Not significant, $* *$ : $p<0.01$ 
The plant height values increased in parallel with the increase in leonardite and nitrogen doses, and the highest plant height was measured at the highest doses of both leonardite and nitrogen. In the study, when the interaction of organic material and nitrogen doses was evaluated together, according to two-year averages, the highest plant height value was obtained in $\mathrm{L}_{2} \mathrm{~N}_{90}(68.38 \mathrm{~cm})$ subject, and the lowest values were found in $\mathrm{L}_{0} \mathrm{~N}_{0}(50.37 \mathrm{~cm})$ subject. $\mathrm{LxN}$ interaction was found to be statistically significant at a level of $\mathrm{p}<0.01$ (Table 4).

Nitrogen is an essential plant nutrient that promotes vegetative growth in plants. Therefore, nitrogen fertilizer applications affect plant height. In their studies carried out with black cumin, Shah (2004), Özgüven and Şekeroğlu (2007), Tuncturk et al. (2012), Yimam et al. (2015), Muhammad et al. (2017), Kizilyıldırım (2019), and Sultana et al. (2019) reported that plant height values increased in parallel with the increase in nitrogen fertilizer doses and/or plant height was positively affected by nitrogen dose applications, similarly to the results of our study.

It has also been reported in the results of many studies that organic material applications such as humic acid and leonardite, which is a source of humic acid, improve the soil properties, and therefore, plant height is positively affected in plants (Laz, 2011; Demirkıran et al., 2012; Betül et al., 2016; Eleroğlu and Korkmaz, 2016; Çöl and Akınerdem, 2017; Yağmur and Okur, 2017).

In the study, the difference between the years was also found to be significant, and the highest plant height values were determined in the second year of the study (Table 4). These differences in plant height values between the years can be explained by the difference in precipitation regimes over the years.

\section{Number of branches}

With respect to the number of branches, the effects of $\mathrm{N}$ doses alone were found to be statistically significant $(\mathrm{p}<0.01)$, while the effects of leonardite doses were found to be insignificant. As an average of leonardite doses, the highest number of branches was statistically found in $\mathrm{N}_{60}\left(3.75\right.$ unit plant $\left.^{-1}\right)$ and $\mathrm{N}_{90}$ (3.81 unit plant ${ }^{-1}$ ) nitrogen doses that constituted the first group, and the lowest values were found in other doses of nitrogen. In the study, when $\mathrm{LxN}$ interaction was examined, while the highest value for the number of branches was found in $\mathrm{L}_{2} \mathrm{~N}_{90}$ (3.95 unit plant ${ }^{-1}$ ) subject, the lowest value was found in $\mathrm{L}_{0} \mathrm{~N}_{0}$ (3.53 unit plant ${ }^{-1}$ ) subject (Table 4).

According to the results of the two-year study carried out with black cumin by Tuncturk et al. (2012), it was reported that nitrogen fertilizer doses increased the number of branches and that the difference between 40-80 kg nitrogen applications per hectare in terms of the number of branches was insignificant. While Özgüven and Şekeroğlu (2007) reported that the highest number of branches was obtained from $90 \mathrm{~kg} \mathrm{~N} \mathrm{ha}^{-1}$ application dose among nitrogen fertilizer dose applications, Kızılyıldırım (2019) and Sultana et al. (2019) reported that it was obtained from $100 \mathrm{~kg} \mathrm{~N} \mathrm{ha}^{-1}$ and $60 \mathrm{~kg} \mathrm{~N} \mathrm{ha}^{-1}$ application doses, respectively. These results in the literature were found to be relatively compatible with the results of our study.

\section{Number of capsules}

With respect to the number of capsules per plant, while the effects of $\mathrm{N}$ doses alone were found to be statistically significant $(\mathrm{p}<0.01)$, the effects of leonardite doses were insignificant. As an average of leonardite doses, the highest number of capsules was found in $\mathrm{N}_{60}\left(6.56\right.$ unit plant $\left.^{-1}\right)$, and the lowest number of capsules was found in the 
control subject in which nitrogen fertilization was not applied $\left(\mathrm{N}_{0}\right)$ with 4.92 unit plant $^{-1}$. In the study, when LxN interaction was examined, the highest values for the number of capsules were statistically found in $\mathrm{L}_{0} \mathrm{~N}_{60}\left(6.85\right.$ unit plant $\left.^{-1}\right)$ and $\mathrm{L}_{2} \mathrm{~N}_{60}$ (6.92 unit plant $^{-1}$ ) subjects that constituted the first group. The lowest number of capsules per plant was found in $\mathrm{L}_{0} \mathrm{~N}_{0}$ subject with 4.70 units. In the study, $\mathrm{LxN}$ interaction was found to be statistically very significant $(\mathrm{p}<0.01)$ (Table 4).

The number of branches per plant affects the number of capsules obtained per plant (Tuncturk et al., 2012). Indeed, in our study, nitrogen doses increased the number of branches, and consequently, more capsules were produced by plants. In their study, Tuncturk et al. (2012) investigated the effects of different nitrogen doses $(0,20,40,60$, and $80 \mathrm{~kg} \mathrm{~N} \mathrm{ha}^{-1}$ ) in black cumin and reported that the number of capsules per plant increased up to the nitrogen dose of $60 \mathrm{~kg} \mathrm{~N} \mathrm{ha}^{-1}$, that the highest number of capsules was achieved with 7.5 capsules at this dose according to the average of two years, and that there was a statistically significant decrease in the number of capsules after $60 \mathrm{~kg} \mathrm{~N} \mathrm{ha}^{-1}$ nitrogen dose. These results were in parallel with the results of our study. It was also reported in some other studies (Özgüven and Şekeroğlu, 2007; Rana et al., 2012; Yimam et al., 2015; Kızılyıldırım, 2019) that the number of capsules in black cumin increased depending on the level of nitrogen fertilizer.

\section{Number of seeds per capsule}

According to the results of the two-year study, the effects of leonardite and nitrogen fertilizer doses on the number of seeds per capsule in black cumin were found to be statistically significant at a level of $\mathrm{p}<0.01$. When the two-year data were considered, the number of seeds per capsule increased in parallel with the increase in leonardite doses, and as an average of nitrogen doses, the highest and lowest values were obtained at $\mathrm{L} 3$ dose (92.52 seeds) and $\mathrm{L}_{0}$ dose (62.32 seeds), respectively (Table 5). The positive effect of leonardite on the number of seeds per capsule can be explained by its contribution by improving the soil structure. Namely, humic substances such as leonardite serve as a reserve in terms of elements such as carbon, nitrogen, Sulphur, and phosphorus, therefore, in the study soil where soil organic matter was quite low (Table 2), it was considered that leonardite, known as the soil conditioner, made some plant nutrients in the soil available to plants, and consequently, flower and seed formation increased. Gürsoy and Kolsarıcı (2017) reported that humic acid doses in the soil covered with leonardite increased the number of seeds per capsule in the colza plant.

When the effects of nitrogen levels were evaluated, it was determined that the number of seeds per capsule increased up to $\mathrm{N}_{60}$ nitrogen dose and decreased statistically significantly after this dose and that the highest value for the number of seeds per capsule, as an average of leonardite doses, was found at $\mathrm{N}_{60}$ nitrogen dose with 100.69 seeds. The lowest values in terms of the number of seeds per capsule were found at $\mathrm{N}_{0}$ dose (53.81 seeds) (Table 5). As in the results of our study, Shah (2004) and Mollafilabi et al. (2010) reported in their study on black cumin that there were significant decreases in the number of seeds per capsule after a certain level of nitrogen. In their study carried out with the datura plant, Esendal et al. (2000) reported that the number of seeds per capsule increased in parallel with the increase in nitrogen doses. On the contrary, Tuncturk et al. (2012) and Kizılyıldirım (2019) determined that nitrogen fertilizer levels in black cumin did not affect the number of seeds per capsule and that the number of seeds per capsule varied between 52.4-55.1 and 110.70-126.73, 
respectively, depending on the levels of nitrogen fertilizer applied. Unlike these data in the literature, significant differences between nitrogen doses in terms of the number of seeds per capsule in our study can be explained by the fact that the soil-plant nutrition relationship occurred differently in terms of nitrogen and other plant nutrients depending on the soil and climatic conditions, in addition to different varieties used.

Table 5. Means of yield components at different leonardite and $N$ doses in black cumin

\begin{tabular}{|c|c|c|c|c|c|c|c|c|c|c|}
\hline \multirow{2}{*}{$\begin{array}{c}\mathbf{L} \\
\text { doses }\end{array}$} & \multirow{2}{*}{$\begin{array}{c}\mathrm{N} \\
\text { doses }\end{array}$} & \multicolumn{3}{|c|}{$\begin{array}{c}\text { Number of seeds per capsule } \\
\text { (number) }\end{array}$} & \multicolumn{3}{|c|}{$\begin{array}{l}\text { Seed weight capsule } \\
\text { (g) }\end{array}$} & \multicolumn{3}{|c|}{$\begin{array}{l}\text { Thousand grain weight } \\
\text { (g) }\end{array}$} \\
\hline & & 2017 & 2018 & Mean $^{I}$ & 2017 & 2018 & Mean $^{I}$ & 2017 & 2018 & Mean $^{1}$ \\
\hline \multirow{4}{*}{$\mathrm{L}_{0}$} & $\mathrm{~N}_{0}$ & 42.00 & 43.94 & 42.971 & 0.44 & 0.47 & 0.46 & 2.10 & 2.26 & 2.18 \\
\hline & $\mathrm{N}_{30}$ & 47.32 & 49.31 & $48.31 \mathrm{~h}$ & 0.51 & 0.52 & 0.51 & 2.30 & 2.30 & 2.30 \\
\hline & $\mathrm{N}_{60}$ & 80.68 & 85.07 & $82.88 \mathrm{~d}$ & 0.54 & 0.55 & 0.54 & 2.35 & 2.28 & 2.32 \\
\hline & $\mathrm{N}_{90}$ & 73.72 & 76.49 & $75.11 \mathrm{e}$ & 0.54 & 0.57 & 0.56 & 2.30 & 2.33 & 2.32 \\
\hline \multicolumn{2}{|c|}{$\mathrm{L}_{0}$ Mean } & 60.93 & 63.70 & $62.32 \mathrm{D}$ & 0.51 & 0.53 & $0.52 \mathrm{~B}$ & 2.26 & 2.29 & $2.28 \mathrm{C}$ \\
\hline \multirow{4}{*}{$\mathrm{L}_{1}$} & $\mathrm{~N}_{0}$ & 48.95 & 50.69 & $49.82 \mathrm{~h}$ & 0.46 & 0.46 & 0.46 & 2.28 & 2.25 & 2.27 \\
\hline & $\mathrm{N}_{30}$ & 54.91 & 58.00 & $56.45 \mathrm{~g}$ & 0.49 & 0.50 & 0.49 & 2.37 & 2.41 & 2.39 \\
\hline & $\mathrm{N}_{60}$ & 91.35 & 93.54 & $92.45 \mathrm{c}$ & 0.54 & 0.56 & 0.55 & 2.29 & 2.36 & 2.33 \\
\hline & $\mathrm{N}_{90}$ & 72.09 & 77.65 & $74.86 \mathrm{e}$ & 0.56 & 0.56 & 0.56 & 2.27 & 2.26 & 2.26 \\
\hline \multicolumn{2}{|c|}{$\mathrm{L}_{1}$ Mean } & 66.82 & 69.97 & $68.40 \mathrm{C}$ & 0.51 & 0.52 & $0.52 \mathrm{~B}$ & 2.30 & 2.32 & $2.31 \mathrm{BC}$ \\
\hline \multirow{4}{*}{$\mathrm{L}_{2}$} & $\mathrm{~N}_{0}$ & 59.52 & 61.29 & $60.41 \mathrm{fg}$ & 0.50 & 0.51 & 0.50 & 2.34 & 2.33 & 2.34 \\
\hline & $\mathrm{N}_{30}$ & 74.63 & 75.90 & $75.27 \mathrm{e}$ & 0.49 & 0.54 & 0.51 & 2.35 & 2.36 & 2.36 \\
\hline & $\mathrm{N}_{60}$ & 111.37 & 114.13 & $112.75 \mathrm{a}$ & 0.54 & 0.57 & 0.56 & 2.34 & 2.36 & 2.35 \\
\hline & $\mathrm{N}_{90}$ & 93.67 & 94.55 & $94.11 \mathrm{c}$ & 0.55 & 0.57 & 0.56 & 2.36 & 2.38 & 2.37 \\
\hline \multicolumn{2}{|c|}{$\mathrm{L}_{2}$ Mean } & 84.79 & 86.47 & $85.63 \mathrm{~B}$ & 0.52 & 0.54 & $0.53 \mathrm{~A}$ & 2.35 & 2.36 & $2.35 \mathrm{~A}$ \\
\hline \multirow{4}{*}{$\mathrm{L}_{3}$} & $\mathrm{~N}_{0}$ & 62.00 & 62.12 & $62.06 \mathrm{f}$ & 0.51 & 0.52 & 0.51 & 2.23 & 2.28 & 2.26 \\
\hline & $\mathrm{N}_{30}$ & 91.10 & 91.34 & $91.27 \mathrm{c}$ & 0.53 & 0.53 & 0.53 & 2.27 & 2.29 & 2.28 \\
\hline & $\mathrm{N}_{60}$ & 114.57 & 114.97 & $114.77 \mathrm{a}$ & 0.53 & 0.57 & 0.55 & 2.38 & 2.37 & 2.37 \\
\hline & $\mathrm{N}_{90}$ & 102.00 & 102.06 & $102.03 \mathrm{~b}$ & 0.55 & 0.60 & 0.58 & 2.35 & 2.37 & 2.36 \\
\hline \multicolumn{2}{|c|}{$\mathrm{L}_{3}$ Mean } & 92.42 & 92.62 & $92.52 \mathrm{~A}$ & 0.53 & 0.55 & $0.54 \mathrm{~A}$ & 2.31 & 2.32 & $2.32 \mathrm{AB}$ \\
\hline \multicolumn{11}{|c|}{ N Mean } \\
\hline \multicolumn{2}{|c|}{$\mathrm{N}_{0}$} & 53.12 & 54.50 & $53.81 \mathrm{~d}$ & 0.47 & 0.49 & $0.49 \mathrm{~d}$ & 2.24 & 2.28 & $2.26 \mathrm{~b}$ \\
\hline \multicolumn{2}{|c|}{$\mathrm{N}_{30}$} & 66.99 & 68.62 & $67.81 \mathrm{c}$ & 0.50 & 0.52 & $0.51 \mathrm{c}$ & 2.32 & 2.34 & $2.33 \mathrm{a}$ \\
\hline \multicolumn{2}{|c|}{$\mathrm{N}_{60}$} & 99.49 & 101.88 & $100.69 \mathrm{a}$ & 0.54 & 0.56 & $0.55 \mathrm{~b}$ & 2.34 & 2.34 & $2.34 \mathrm{a}$ \\
\hline \multicolumn{2}{|c|}{$\mathrm{N}_{90}$} & 85.37 & 87.68 & $86.53 \mathrm{~b}$ & 0.55 & 0.57 & $0.56 \mathrm{a}$ & 2.32 & 2.34 & $2.33 \mathrm{a}$ \\
\hline \multicolumn{2}{|c|}{ Means } & $76.24 \mathrm{~B}$ & $78.17 \mathrm{~A}$ & & $0.52 \mathrm{~B}$ & $0.54 \mathrm{~A}$ & & 2.31 & 2.32 & \\
\hline \multicolumn{2}{|c|}{$\mathrm{CV}(\%)$} & & 5.93 & & & 4.19 & & & 7.1 & \\
\hline \multicolumn{2}{|c|}{ Year (Y) } & & $*$ & & & $* *$ & & & $\mathrm{~ns}$ & \\
\hline \multicolumn{2}{|c|}{$\mathrm{L}$} & & $* *$ & & & $* *$ & & & $* *$ & \\
\hline \multicolumn{2}{|c|}{$\mathrm{N}$} & & $* *$ & & & $* *$ & & & $* *$ & \\
\hline \multirow{2}{*}{\multicolumn{2}{|c|}{$\mathrm{LxN}$}} & & $* *$ & & & ns & & & $\mathrm{ns}$ & \\
\hline & & & $\mathrm{ns}$ & & & ns & & & $\mathrm{ns}$ & \\
\hline
\end{tabular}

$\mathrm{L}_{0}=$ Control, $\mathrm{L}_{1}=1000 \mathrm{~kg} \mathrm{ha}^{-1}$ leonardite, $\mathrm{L}_{2}=2000 \mathrm{~kg} \mathrm{ha}^{-1}$ leonardite, $\mathrm{L}_{3}=3000 \mathrm{~kg} \mathrm{ha}^{-1}$ leonardite, $\mathrm{N}_{0}=$ Control, $\mathrm{N}_{30}=30 \mathrm{~kg} \mathrm{ha}^{-1}$ nitrogen, $\mathrm{N}_{60}=60 \mathrm{~kg} \mathrm{ha}^{-1}$ nitrogen, $\mathrm{N}_{90}=90 \mathrm{~kg} \mathrm{ha}^{-1}$ nitrogen, ${ }^{l}$ : The difference between the means indicated by the same letter in the same column and group is not significant, CV: Coefficient of variation, ns: Not significant, *: $\mathrm{p}<0.05, * *$ : $<<0.01$

When $\mathrm{LxN}$ interaction was examined, the highest value for the number of seeds per capsule was statistically obtained from $\mathrm{L}_{3} \mathrm{~N}_{60}$ (114.77 seeds) and $\mathrm{L}_{2} \mathrm{~N}_{60}$ (112.75 seeds) applications, which constituted the first group. The lowest value was found in $\mathrm{L}_{0} \mathrm{~N}_{0}$ (42.97 seeds). In the study, the highest values for the number of seeds per capsule were found in the second year of the study as an average of leonardite and nitrogen doses. 
With respect to the number of seeds per capsule, the difference between the years $(\mathrm{p}<0.05)$ and $\mathrm{LxN}$ interaction $(\mathrm{p}<0.01)$ were found to be statistically significant (Table 5).

\section{Seed weight capsule}

The effects of leonardite and nitrogen fertilizer doses on the seed weight capsule in black cumin were found to be statistically significant at a level of $p<0.01$. When the two-year data were considered, seed weight capsule increased in parallel with the increase in leonardite doses, and as an average of nitrogen doses, the highest values were obtained at $\mathrm{L}_{3}$ dose $(0.54 \mathrm{~g})$ and $\mathrm{L}_{2}$ dose $(0.53 \mathrm{~g})$, respectively (Table 5). The highest seed weight capsule value was 0.56 with $\mathrm{N}_{90}$ nitrogen doses as an average of leonardite doses (Table 5).

\section{Thousand-seed weight}

In the study, nitrogen doses had a statistically significant effect at a $p<0.01$ level on the thousand grain weight of black cumin, and the highest thousand seed weight values were found at other nitrogen doses $\left(\mathrm{N}_{30}, \mathrm{~N}_{60}\right.$, and $\left.\mathrm{N}_{90}\right)$, except for the control $\left(\mathrm{N}_{0}\right)$ subject. The effects of leonardite applications were found to be significant at a $p<0.01$ level (Table 5). The highest thousand seed weight value was obtaned from $\mathrm{L}_{2}(2.35 \mathrm{~g})$, followed by $\mathrm{L}_{3}(2.32 \mathrm{~g})$ leonardite doses. In the studies carried out by Başalma (1999) in the colza plant, by Esendal et al. (2000) in the datura plant, and by Ashraf et al. (2006) and Muhammad et al. (2017) in black cumin, the researchers determined that nitrogen fertilizer doses significantly increased thousand grain weight compared to the control. On the other hand, Tuncturk et al. (2012) and Kizilyıldırım (2019) reported that no significant differences were observed between nitrogen fertilizer doses in terms of thousand grain weight in black cumin.

\section{Seed yield}

In the study, when the effects of leonardite applications were examined, the highest seed yield, as an average of nitrogen doses, was statistically found at $\mathrm{L}_{3}\left(1673.3 \mathrm{~kg} \mathrm{ha}^{-1}\right)$ and $\mathrm{L}_{2}\left(1645.8 \mathrm{~kg} \mathrm{ha}^{-1}\right)$ leonardite doses included in the first group. In terms of seed yield, the lowest results were obtained at $\mathrm{L}_{0}$ and $\mathrm{L}_{1}$ doses. This difference between leonardite applications was found to be statistically very significant $(\mathrm{p}<0.01)($ Table 6$)$. It was considered that leonardite applied to the soil prevented the evaporation of water in the plant root zone and conserved the water in the soil, and consequently, drought and temperature stress occurred, and it increased the effectiveness of the existing water in the soil under the climate and soil conditions of Siirt province. Accordingly, the application of leonardite in these and similar soils, which are low in organic matter, plays a role in the conversion of plant nutrients in the soil into receivable form and increases the efficiency of the use of nutrients by plants. Therefore, humic substances such as leonardite have indirect effects on the yield increase in plants by increasing the uptake of minerals. In our study, it was considered to be effective on the increase in the seed yield of black cumin, depending on the increase in leonardite doses. Similar studies carried out in different plants on this subject support the results of our study. For example, it was reported that humic acid dose applications increased the seed yield in colza (Gürsoy et al., 2016) and tuber yield in the potato plant (Çöl and Akınerdem, 2017) compared to the control, that leonardite applications increased the tuber yield in 
potato (Şanlı and Karadoğan, 2011) compared to the control, and that leonardite applications increased the amount of dry matter and the levels of some macronutrients (Adiloğlu et al., 2017) in the rye (Secale cerale L.) plant compared to the control.

Table 6. Means of seed yield, fixed oil and essential oil ratio at different leonardite and nitrogen doses in black cumin

\begin{tabular}{|c|c|c|c|c|c|c|c|c|c|c|}
\hline \multirow{2}{*}{\multicolumn{2}{|c|}{$\underset{\text { doses }}{\mathbf{L}} \underset{\text { doses }}{\mathrm{N}}$}} & \multicolumn{3}{|c|}{ Seed yield $\left(\mathrm{kg} \mathrm{ha}^{-1}\right)$} & \multicolumn{3}{|c|}{ Fixed oil ratio (\%) } & \multicolumn{3}{|c|}{ Essential oil (\%) } \\
\hline & & 2017 & 2018 & Mean $^{I}$ & 2017 & 2018 & Mean ${ }^{I}$ & 2017 & 2018 & $\operatorname{Mean}^{1}$ \\
\hline \multirow{4}{*}{$\mathrm{L}_{0}$} & $\mathrm{~N}_{0}$ & 736.7 & 790.0 & 763.3 & 36.08 & 37.00 & 36.54 & 0.23 & 0.25 & 0.24 \\
\hline & $\mathrm{N}_{30}$ & 1100.0 & 1120.0 & 1110.0 & 36.34 & 37.22 & 36.78 & 0.26 & 0.26 & 0.26 \\
\hline & $\mathrm{N}_{60}$ & 1783.3 & 1837.7 & 1810.0 & 36.80 & 37.74 & 37.27 & 0.28 & 0.29 & 0.28 \\
\hline & $\mathrm{N}_{90}$ & 1580.0 & 1710.0 & 1645.0 & 37.30 & 37.63 & 37.47 & 0.28 & 0.30 & 0.29 \\
\hline $\mathrm{L}_{0} \mathrm{I}$ & Mean & 1300.0 & 1364.2 & $1332.0 \mathrm{~B}$ & 36.63 & 37.40 & $37.02 \mathrm{~B}$ & 0.26 & 0.28 & $0.27 \mathrm{~B}$ \\
\hline \multirow{4}{*}{$\mathrm{L}_{1}$} & $\mathrm{~N}_{0}$ & 1023.3 & 1053.3 & 1038.3 & 36.66 & 37.58 & 37.12 & 0.25 & 0.26 & 0.25 \\
\hline & $\mathrm{N}_{30}$ & 1150.0 & 1170.0 & 1160.0 & 36.45 & 37.39 & 36.92 & 0.26 & 0.28 & 0.27 \\
\hline & $\mathrm{N}_{60}$ & 1810.0 & 1863.3 & 1836.7 & 37.58 & 38.25 & 37.92 & 0.28 & 0.31 & 0.29 \\
\hline & $\mathrm{N}_{90}$ & 1636.7 & 1756.7 & 1696.7 & 37.87 & 38.20 & 38.03 & 0.29 & 0.31 & 0.30 \\
\hline $\mathrm{L}_{1} \mathrm{I}$ & Mean & 1405.0 & 1460.8 & $1432.9 \mathrm{~B}$ & 37.14 & 37.86 & $37.50 \mathrm{~A}$ & 0.27 & 0.29 & $0.28 \mathrm{~B}$ \\
\hline \multirow{4}{*}{$\mathrm{L}_{2}$} & $\mathrm{~N}_{0}$ & 1290.0 & 1356.7 & 1323.3 & 36.61 & 37.59 & 37.10 & 0.26 & 0.28 & 0.27 \\
\hline & $\mathrm{N}_{30}$ & 1226.7 & 1493.3 & 1360.0 & 36.40 & 37.30 & 36.85 & 0.27 & 0.30 & 0.29 \\
\hline & $\mathrm{N}_{60}$ & 1886.7 & 2046.7 & 1966.7 & 37.00 & 37.27 & 37.13 & 0.30 & 0.32 & 0.31 \\
\hline & $\mathrm{N}_{90}$ & 1910.0 & 1956.7 & 1933.3 & 38.27 & 38.60 & 38.43 & 0.30 & 0.33 & 0.31 \\
\hline $\mathrm{L}_{2}$ & Mean & 1578.3 & 1713.3 & $1645.8 \mathrm{~A}$ & 37.07 & 37.69 & $37.38 \mathrm{~A}$ & 0.28 & 0.31 & $0.30 \mathrm{~A}$ \\
\hline \multirow{4}{*}{$\mathrm{L}_{3}$} & $\mathrm{~N}_{0}$ & 1120.0 & 1206.7 & 1163.3 & 36.44 & 37.11 & 36.77 & 0.25 & 0.28 & 0.27 \\
\hline & $\mathrm{N}_{30}$ & 1566.7 & 1606.7 & 1586.7 & 36.46 & 37.36 & 36.86 & 0.27 & 0.30 & 0.28 \\
\hline & $\mathrm{N}_{60}$ & 2043.3 & 2110.0 & 2076.7 & 37.69 & 38.02 & 37.85 & 0.29 & 0.31 & 0.30 \\
\hline & $\mathrm{N}_{90}$ & 1870.0 & 1863.3 & 1866.7 & 37.86 & 37.93 & 37.89 & 0.30 & 0.32 & 0.31 \\
\hline $\mathrm{L}_{3}$ & Mean & 1650.0 & 1696.6 & $1673.3 \mathrm{~A}$ & 37.11 & 37.61 & $37.36 \mathrm{~A}$ & 0.27 & 0.30 & $0.29 \mathrm{~A}$ \\
\hline \multicolumn{11}{|c|}{ N Mean } \\
\hline & $\overline{N_{0}}$ & 1042.5 & 1101.6 & $1072.1 \mathrm{~d}$ & 36.45 & 37.34 & 36. & 0.25 & 0.27 & $0.26 \mathrm{c}$ \\
\hline & $\mathrm{N}_{30}$ & 1260.8 & 1347.5 & $1304.2 \mathrm{c}$ & 36.41 & 37.35 & 36. & 0.26 & 0.29 & $0.27 \mathrm{~b}$ \\
\hline & $\mathrm{N}_{60}$ & 1880.8 & 1964.2 & $1922.5 \mathrm{a}$ & 37.27 & 37.83 & $37.55 \mathrm{~b}$ & 0.29 & 0.31 & $0.30 \mathrm{a}$ \\
\hline & $\mathrm{N}_{90}$ & 1749.2 & 1821.6 & $1785.4 \mathrm{~b}$ & 37.83 & 38.09 & $37.96 \mathrm{a}$ & 0.29 & 0.32 & $0.31 \mathrm{a}$ \\
\hline \multicolumn{2}{|c|}{ Means } & \multicolumn{3}{|c|}{$1483.3 \mathrm{~B} \quad 1558.7 \mathrm{~A}$} & \multicolumn{3}{|c|}{$36.99 \mathrm{~B} \quad 37.65 \mathrm{~A}$} & $0.27 \mathrm{~B}$ & $0.29 \mathrm{~A}$ & \\
\hline \multirow{2}{*}{\multicolumn{2}{|c|}{$\begin{array}{l}\text { CV (\%) } \\
\text { Year (Y) }\end{array}$}} & \multicolumn{3}{|c|}{11.85} & \multicolumn{3}{|c|}{1.33} & \multicolumn{3}{|c|}{4.60} \\
\hline & & \multicolumn{3}{|c|}{$*$} & \multicolumn{3}{|c|}{$* *$} & \multicolumn{3}{|c|}{$* *$} \\
\hline & $\mathrm{L}$ & \multirow{2}{*}{\multicolumn{3}{|c|}{$\begin{array}{l}* * \\
* *\end{array}$}} & \multicolumn{3}{|c|}{$* *$} & \multicolumn{3}{|c|}{$* *$} \\
\hline & $\mathrm{N}$ & & & & \multicolumn{3}{|c|}{ ** } & \multicolumn{3}{|c|}{$* *$} \\
\hline & & \multicolumn{3}{|c|}{$* *$} & \multirow{2}{*}{\multicolumn{3}{|c|}{ ns }} & & ns & \\
\hline$L x I$ & & \multicolumn{3}{|c|}{ ns } & & & & & ns & \\
\hline
\end{tabular}

$\mathrm{L}_{0}=$ Control, $\mathrm{L}_{1}=1000 \mathrm{~kg} \mathrm{ha}^{-1}$ leonardite, $\mathrm{L}_{2}=2000 \mathrm{~kg} \mathrm{ha}^{-1}$ leonardite, $\mathrm{L}_{3}=3000 \mathrm{~kg} \mathrm{ha}^{-1}$ leonardite, $\mathrm{N}_{0}=$ Control, $\mathrm{N}_{30}=30 \mathrm{~kg} \mathrm{ha}^{-1}$ nitrogen, $\mathrm{N}_{60}=60 \mathrm{~kg} \mathrm{ha}^{-1}$ nitrogen, $\mathrm{N}_{90}=90 \mathrm{~kg} \mathrm{ha}^{-1}$ nitrogen, ${ }^{l}$ : The difference between the means indicated by the same letter in the same column and group is not significant, CV: Coefficient of variation, ns: Not significant, *: $\mathrm{p}<0.05, * *$ : $<<0.01$

When the effects of nitrogen doses alone were examined, as an average of leonardite doses, the highest seed yield was found to be $1922.5 \mathrm{~kg} \mathrm{ha}^{-1}$ at $\mathrm{N}_{60}$ dose, and the lowest seed yield was found to be $1072.1 \mathrm{~kg} \mathrm{ha}^{-1}$ at $\mathrm{N}_{0}$ dose, and seed yield decreased significantly at $\mathrm{N}_{90}$ dose. With respect to seed yield, this difference between nitrogen fertilizer doses was found to be statistically significant at a $\mathrm{p}<0.01$ level (Table 6). It was also reported in the results of some studies that nitrogen fertilization in black cumin 
had significant and positive effects on seed yield. When these studies were reviewed, it was reported that the highest seed yield in black cumin was obtained from $60 \mathrm{~kg} \mathrm{~N}^{-1}$ nitrogen dose under the ecological conditions of India (Shah, 2004), Çukurova-Turkey (Özgüven and Şekeroğlu, 2007), Van-Turkey (Tuncturk et al., 2012), Ethiopia (Yimam et al., 2015), and Eskişehir-Turkey (Sağlam, 2018), from 30-60 kg N ha-1 nitrogen dose under the conditions of South Korea (Ashraf et al., 2006), from $30 \mathrm{~kg} \mathrm{~N} \mathrm{ha}^{-1}$ nitrogen dose in the ecology of Iraq-Sulaymaniyah (Muhammad et al., 2017), and from $80 \mathrm{~kg} \mathrm{~N} \mathrm{ha}^{-1}$ nitrogen dose under the climatic and soil conditions of KahramanmaraşTurkey (Kızılyıldırım, 2019).

It can be said that the results of our study are generally compatible with these data in the literature. The fact that nitrogen doses have different effects in different ecologies in terms of the seed yield of black cumin can be explained by different physical and chemical properties (especially organic matter) of soils where the study was carried out, along with the genotypic difference of the plant material used.

In the study, the difference between the years in terms of seed yield was also found to be statistically significant $(\mathrm{p}<0.05)$, and the highest values, as the average of leonardite and nitrogen doses, were found in the second year of the study (Table 6). It was considered that this difference between the years in terms of seed yield was due to differences in precipitation and temperature between the years.

In the study, although the LxN interaction was found to be statistically insignificant, it was remarkable that the seed yield was high in the treatments in which leonardite and nitrogen fertilizer were applied together at increasing ratios (e.g., such as $\mathrm{L}_{2} \mathrm{~N}_{60}$ and $\mathrm{L}_{3} \mathrm{~N}_{60}$ ) (Table 6), which was considered as a significant result in that soil-conditioning organic materials such as leonardite increase the effectiveness of chemical fertilizers.

\section{Fixed oil}

One of the most critical factors that determine the seed quality in black cumin is the fixed oil ratio (Akgül, 1993). In the study, it was observed that leonardite applications increased the fixed oil ratio in the seeds of the black cumin plant. It was determined that this increase was statistically very significant at a $(\mathrm{p}<0.01)$ level compared to the subject without leonardite application $\left(\mathrm{L}_{0}\right)$ and that the highest values were obtained from other applications, except for $\mathrm{L}_{0}$. The fixed oil ratio of black cumin varied between 37.02-37.50\% along with leonardite applications (Table 6).

When nitrogen fertilizer doses were examined alone, it was determined that the fixed oil ratio of black cumin seeds increased in parallel with the increase in nitrogen doses and that the highest fixed oil ratio was obtained from $\mathrm{N}_{90}$ nitrogen dose with $37.96 \%$ as an average of leonardite doses. This difference between nitrogen fertilizer doses in terms of fixed oil ratio was found to be statistically significant at a $\mathrm{p}<0.01$ level (Table 6).

While the fatty acid composition of seeds varies by species and genotypes (Karaca and Aytaç, 2007), different cultural applications in the planting-harvesting process (Küçükemre, 2009; Arslan et al., 2011; Kulan et al., 2012) and the ecological (Karaca and Aytaç, 2007) and topographic (Yüksek et al., 2016) differences also affect the oil ratio. In this sense, different results were obtained with respect to the effects of nitrogen fertilization on the fixed oil ratio consisting of saturated and unsaturated fatty acids. For example, it was reported that different doses of nitrogen fertilization did not generally affect the fixed oil ratio in black cumin (Shah, 2004; Özgüven and Şekeroğlu, 2007; Kizılyıldırım, 2019). On the contrary, it was reported that significant differences 
occurred between nitrogen fertilizer doses in terms of fixed oil ratio in the fennel (Foeniculum vulgare Mill.) plant (Tunçtürk et al., 2011) and oil ratio in the safflower (Carthamus tinctorius L.) plant (Katar et al., 2012).

It was considered that the emergence of significant differences between leonardite and nitrogen applications in terms of fixed oil ratio in the research soil, where soil organic matter, and accordingly, the amount of nitrogen in the soil were low, was affected by the increased availability of plant nutrients and the synergistic relationship between some nutrients. Nevertheless, it was reported that black cumin seeds contained fixed oil at ratios varying between 21.83-40.58\% (Akgül, 1993; Türker and Bayrak, 1997; Kalçın, 2003; Kulan et al., 2012; Ertaş, 2016; Selicioğlu, 2018; Kızıllyıldırım, 2019), and it was observed that the fixed oil ratio values obtained as a result of leonardite and nitrogen applications in our study were within these limits in the literature.

\section{Essential oil}

In the study, both leonardite and nitrogen fertilizer doses had statistically very significant $(p<0.01)$ effects on the essential oil of black cumin seeds. While the highest essential oil in leonardite applications was found at $\mathrm{L}_{2}$ and $\mathrm{L}_{3}$ doses $(0.30 \%$ and $0.29 \%$, respectively) as an average of years and nitrogen doses, the highest essential oil in nitrogen fertilizer applications was found at $\mathrm{N}_{60}(0.30 \%)$ and $\mathrm{N}_{90}$ doses $(0.31 \%)$ as an average of years and leonardite doses (Table 6).

According to the result of the study, it was observed that leonardite applications and nitrogen fertilizer applications, also known as organic fertilizer sources, increased the essential oil of black cumin seeds. Our results obtained by nitrogen fertilizer dose applications were found to be consistent with the results obtained by Türközü (2005), Özgüven and Şekeroğlu (2007), and Kızılyıldırım (2019). For example, in some other studies in which nitrogen fertilizer applications were performed, Yildirım and Kan (2006) and Tunçtürk et al. (2011) reported that nitrogen fertilizer doses had no effect on essential oil in fennel, contrary to the results of our study.

\section{Essential oil components}

Essential oil components obtained by the Headspace GC-MS analysis of black cumin essential oil are presented in Table 7. A total of 6 components were found in black cumin essential oil. The main component of black cumin essential oil is thymoquinone. In our study, the effects of leonardite and nitrogen doses alone and together on thymoquinone content were found to be statistically significant $(\mathrm{p}<0.01)$. Accordingly, it was observed that the composition of thymoquinone of the essential oil of black cumin seeds increased in parallel with the increase in both leonardite and nitrogen doses and that the highest values were obtained at high doses. Indeed, this situation also manifested itself in the $\mathrm{LxN}$ interaction, and the highest thymoquinone content was found in $\mathrm{L}_{3} \mathrm{~N}_{90}$ subject by $47.09 \%$ (Table 7). Another major component of black cumin essential oil is P-cymene, and leonardite and nitrogen doses had a very significant $(\mathrm{p}<0.01)$ effect on P-cymene content. The highest P-cymene content and the lowest $\mathrm{P}$-cymene content were found at $\mathrm{L}_{3}$ dose by $41.66 \%$ and at $\mathrm{L}_{0}(41.27 \%)$ leonardite dose, respectively, as an average of years and nitrogen doses. When the effects of nitrogen doses alone were reviewed, the highest P-cymene content and the lowest P-cymene content were found at $\mathrm{N}_{90}$ dose by $43.11 \%$ and at $\mathrm{N}_{0}$ nitrogen dose by $38.67 \%$, respectively, as an average of years and leonardite doses (Table 7). 
Table 7. The effect of leonardite and nitrogen fertilizer doses on the components of black cumin essential oil

\begin{tabular}{|c|c|c|c|c|c|c|c|c|c|}
\hline \multirow{2}{*}{ LxN } & \multicolumn{3}{|c|}{ Thymoquinone } & \multicolumn{3}{|c|}{ Beta-pinene } & \multicolumn{3}{|c|}{ Sabinene } \\
\hline & 2017 & 2018 & Mean" & 2017 & 2018 & Mean* & 2017 & 2018 & Mean $^{*}$ \\
\hline $\mathrm{L}_{0} \mathrm{~N}_{0}$ & 44.52 & 44.09 & $44.31 \mathrm{~d}$ & 5.28 & 5.30 & $5.29 \mathrm{f}$ & 2.56 & 2.64 & 2.60 \\
\hline $\mathrm{L}_{0} \mathrm{~N}_{30}$ & 44.58 & 44.67 & $44.63 \mathrm{~cd}$ & 5.31 & 5.35 & $5.33 \mathrm{ef}$ & 2.62 & 2.66 & 2.64 \\
\hline $\mathrm{L}_{0} \mathrm{~N}_{60}$ & 45.65 & 45.60 & $45.63 \mathrm{~b}$ & 5.34 & 5.38 & $5.36 \mathrm{de}$ & 2.68 & 2.74 & 2.71 \\
\hline $\mathrm{L}_{0} \mathrm{~N}_{90}$ & 45.70 & 45.80 & $45.75 \mathrm{~b}$ & 5.57 & 5.60 & $5.59 \mathrm{bc}$ & 2.84 & 2.88 & 2.86 \\
\hline $\mathrm{L}_{1} \mathrm{~N}_{0}$ & 44.68 & 44.72 & $44.70 \mathrm{~cd}$ & 5.31 & 5.33 & $5.32 \mathrm{ef}$ & 2.57 & 2.61 & 2.59 \\
\hline $\mathrm{L}_{1} \mathrm{~N}_{30}$ & 44.75 & 44.73 & $44.74 \mathrm{~cd}$ & 5.34 & 5.35 & $5.35 \mathrm{de}$ & 2.66 & 2.69 & 2.68 \\
\hline $\mathrm{L}_{1} \mathrm{~N}_{60}$ & 45.73 & 45.73 & $45.73 \mathrm{~b}$ & 5.52 & 5.55 & $5.54 \mathrm{c}$ & 2.72 & 2.76 & 2.74 \\
\hline $\mathrm{L}_{1} \mathrm{~N}_{90}$ & 45.72 & 45.74 & $45.73 \mathrm{~b}$ & 5.61 & 5.63 & $5.62 \mathrm{~b}$ & 2.86 & 2.86 & 2.86 \\
\hline $\mathrm{L}_{2} \mathrm{~N}_{0}$ & 44.74 & 44.71 & $44.72 \mathrm{~cd}$ & 5.33 & 5.35 & $5.34 \mathrm{ef}$ & 2.59 & 2.66 & 2.62 \\
\hline $\mathrm{L}_{2} \mathrm{~N}_{30}$ & 44.84 & 44.85 & $44.84 \mathrm{c}$ & 5.37 & 5.36 & $5.35 \mathrm{de}$ & 2.67 & 2.69 & 2.68 \\
\hline $\mathrm{L}_{2} \mathrm{~N}_{60}$ & 45.81 & 45.89 & $45.85 \mathrm{~b}$ & 5.55 & 5.60 & $5.58 \mathrm{bc}$ & 2.73 & 2.75 & 2.74 \\
\hline $\mathrm{L}_{2} \mathrm{~N}_{90}$ & 47.50 & 47.34 & $47.42 \mathrm{a}$ & 5.61 & 5.61 & $5.61 \mathrm{~b}$ & 2.87 & 2.90 & 2.89 \\
\hline $\mathrm{L}_{3} \mathrm{~N}_{0}$ & 44.77 & 44.75 & $44.76 \mathrm{c}$ & 5.36 & 5.34 & $5.35 \mathrm{de}$ & 2.59 & 2.66 & 2.63 \\
\hline $\mathrm{L}_{3} \mathrm{~N}_{30}$ & 44.85 & 44.86 & $44.86 \mathrm{c}$ & 5.37 & 5.42 & $5.40 \mathrm{~d}$ & 2.66 & 2.71 & 2.68 \\
\hline $\mathrm{L}_{3} \mathrm{~N}_{60}$ & 45.84 & 45.82 & $45.83 \mathrm{~b}$ & 5.59 & 5.63 & $5.61 \mathrm{~b}$ & 2.74 & 2.77 & 2.76 \\
\hline $\mathrm{L}_{3} \mathrm{~N}_{90}$ & 47.03 & 47.15 & $47.09 \mathrm{a}$ & 5.65 & 5.72 & $5.69 \mathrm{a}$ & 2.87 & 2.89 & 2.88 \\
\hline Mean & 45.42 & 45.40 & & 5.43 & 5.47 & & $2.70 \mathrm{~b}$ & 2.74 & \\
\hline $\mathrm{CV}(\%)$ & \multicolumn{3}{|c|}{1.85} & \multicolumn{3}{|c|}{2.16} & \multicolumn{2}{|c|}{2.09} & \\
\hline $\mathrm{L}_{0}$ & & & $45.08 \mathrm{~b}$ & & & $5.39 \mathrm{c}$ & & & 2.70 \\
\hline $\mathrm{L}_{1}$ & & & $45.23 \mathrm{~b}$ & & & $5.46 \mathrm{~b}$ & & & 2.72 \\
\hline $\mathrm{L}_{2}$ & & & $45.71 \mathrm{a}$ & & & $5.47 \mathrm{~b}$ & & & 2.73 \\
\hline $\mathrm{L}_{3}$ & & & $45.63 \mathrm{a}$ & & & $5.51 \mathrm{a}$ & & & 2.74 \\
\hline $\mathrm{N}_{0}$ & & & $44.62 \mathrm{c}$ & & & $5.33 \mathrm{~d}$ & & & $2.61 \mathrm{~d}$ \\
\hline $\mathrm{N}_{30}$ & & & $44.77 \mathrm{c}$ & & & $5.36 \mathrm{c}$ & & & $2.67 \mathrm{c}$ \\
\hline $\mathrm{N}_{60}$ & & & $45.76 \mathrm{~b}$ & & & $5.49 \mathrm{~b}$ & & & $2.74 \mathrm{~b}$ \\
\hline \multirow[t]{2}{*}{$\mathrm{N}_{90}$} & & & $46.50 \mathrm{a}$ & & & $5.63 \mathrm{a}$ & & & $2.87 \mathrm{a}$ \\
\hline & \multicolumn{3}{|c|}{$\mathrm{L}^{* *}, \mathrm{~N}^{* *}, \mathrm{LxN}^{* * *}$} & \multicolumn{3}{|c|}{$\mathrm{L}^{* *}, \mathrm{~N}^{* *}, \mathrm{LxN}^{* * *}$} & \multicolumn{3}{|c|}{$\mathrm{Y}^{* *}, \mathrm{~N}^{* * *}$} \\
\hline \multirow{2}{*}{$\mathbf{L x N}$} & \multicolumn{3}{|c|}{ Limonene } & \multicolumn{3}{|c|}{ P-cymene } & \multicolumn{3}{|c|}{ Linalool } \\
\hline & 2017 & 2018 & Mean* & 2017 & 2018 & Mean* & 2017 & 2018 & Mean* \\
\hline $\mathrm{L}_{0} \mathrm{~N}_{0}$ & 2.02 & 2.05 & 2.03 & 37.94 & 39.08 & 38.51 & 1.86 & 1.97 & 1.91 \\
\hline $\mathrm{L}_{0} \mathrm{~N}_{30}$ & 2.24 & 2.17 & 2.21 & 41.55 & 42.35 & 41.95 & 2.22 & 2.25 & 2.24 \\
\hline $\mathrm{L}_{0} \mathrm{~N}_{60}$ & 2.25 & 2.24 & 2.25 & 41.47 & 41.81 & 41.64 & 2.37 & 2.33 & 2.35 \\
\hline $\mathrm{L}_{0} \mathrm{~N}_{90}$ & 2.32 & 2.27 & 2.30 & 42.67 & 43.27 & 42.97 & 2.48 & 2.39 & 2.44 \\
\hline $\mathrm{L}_{1} \mathrm{~N}_{0}$ & 2.10 & 2.12 & 2.11 & 38.21 & 38.93 & 38.57 & 1.93 & 1.95 & 1.94 \\
\hline $\mathrm{L}_{1} \mathrm{~N}_{30}$ & 2.27 & 2.25 & 2.26 & 41.57 & 42.25 & 41.91 & 2.21 & 2.25 & 2.23 \\
\hline $\mathrm{L}_{1} \mathrm{~N}_{60}$ & 2.29 & 2.29 & 2.29 & 41.81 & 42.62 & 42.21 & 2.36 & 2.32 & 2.34 \\
\hline $\mathrm{L}_{1} \mathrm{~N}_{90}$ & 2.32 & 2.34 & 2.33 & 42.76 & 43.35 & 43.05 & 2.48 & 2.47 & 2.48 \\
\hline $\mathrm{L}_{2} \mathrm{~N}_{0}$ & 2.15 & 2.12 & 2.13 & 38.42 & 38.85 & 38.63 & 1.94 & 1.93 & 1.94 \\
\hline $\mathrm{L}_{2} \mathrm{~N}_{30}$ & 2.29 & 2.28 & 2.29 & 41.57 & 41.96 & 41.76 & 2.27 & 2.28 & 2.27 \\
\hline $\mathrm{L}_{2} \mathrm{~N}_{60}$ & 2.32 & 2.31 & 2.32 & 41.83 & 42.50 & 42.17 & 2.38 & 2.40 & 2.39 \\
\hline $\mathrm{L}_{2} \mathrm{~N}_{90}$ & 2.37 & 2.37 & 2.37 & 42.81 & 43.67 & 43.24 & 2.50 & 2.52 & 2.51 \\
\hline $\mathrm{L}_{3} \mathrm{~N}_{0}$ & 2.16 & 2.15 & 2.16 & 38.67 & 39.23 & 38.95 & 1.89 & 1.98 & 1.94 \\
\hline $\mathrm{L}_{3} \mathrm{~N}_{30}$ & 2.32 & 2.27 & 2.29 & 41.85 & 42.41 & 42.13 & 2.29 & 2.33 & 2.31 \\
\hline $\mathrm{L}_{3} \mathrm{~N}_{60}$ & 2.28 & 2.30 & 2.29 & 41.99 & 42.79 & 42.39 & 2.39 & 2.43 & 2.41 \\
\hline $\mathrm{L}_{3} \mathrm{~N}_{90}$ & 2.35 & 2.39 & 2.37 & 42.89 & 43.46 & 43.17 & 2.51 & 2.50 & 2.50 \\
\hline Mean & 2.25 & 2.24 & & $41.12 \mathrm{~b}$ & $41.78 \mathrm{a}$ & & 2.25 & 2.27 & \\
\hline $\mathrm{CV}(\%)$ & & & & & & & & & \\
\hline $\mathrm{L}_{0}$ & & & $2.20 \mathrm{~b}$ & & & $41.27 \mathrm{c}$ & & & $2.23 \mathrm{~b}$ \\
\hline $\mathrm{L}_{1}$ & & & $2.25 \mathrm{a}$ & & & $41.44 \mathrm{bc}$ & & & $2.25 \mathrm{~b}$ \\
\hline $\mathrm{L}_{2}$ & & & $2.28 \mathrm{a}$ & & & $41.45 \mathrm{~b}$ & & & $2.28 \mathrm{a}$ \\
\hline $\mathrm{L}_{3}$ & & & $2.28 \mathrm{a}$ & & & $41.66 \mathrm{a}$ & & & $2.29 \mathrm{a}$ \\
\hline $\mathrm{N}_{0}$ & & & $2.11 \mathrm{c}$ & & & $38.67 \mathrm{c}$ & & & $1.93 \mathrm{~d}$ \\
\hline $\mathrm{N}_{30}$ & & & $2.26 \mathrm{~b}$ & & & $41.94 \mathrm{~b}$ & & & $2.26 \mathrm{c}$ \\
\hline $\mathrm{N}_{60}$ & & & $2.28 \mathrm{~b}$ & & & $42.10 \mathrm{~b}$ & & & $2.37 \mathrm{~b}$ \\
\hline $\mathrm{N}_{90}$ & & & $2.34 \mathrm{a}$ & & & $43.11 \mathrm{a}$ & & & $2.48 \mathrm{a}$ \\
\hline & & $\mathrm{L}^{* *}, \mathrm{~N}$ & & & $Y^{* *}, L^{* *}$, & & & $\mathrm{L}^{* *}, \mathrm{~N}^{*}$ & \\
\hline
\end{tabular}

L: Leonardite, N: Nitrogen, CV: Coefficient of variation, Y: Year, *: The difference between the means indicated by the same letter in the same column and group is not significant, $* *: \mathrm{p}<0.01$ 
In the study, other components found in black cumin essential oil were beta-pinene, sabinene, limonene, and linalool. It was determined that the amounts of these components were affected by leonardite (except for sabinene) and nitrogen dose applications and that the components generally had the highest values at the highest leonardite and nitrogen doses (Table 7).

In other studies on black cumin, the main component was determined to be p-cymene (47.4\%, 49.06\%, and 43.58\%, respectively) by Orchid et al. (2004), Ashraf et al. (2006), and Toma et al. (2010). Moretti et al. (2004), Orchid et al. (2004), Toma et al. (2010), and Harzallah et al. (2011) determined that thymoquinone ratios in black cumin essential oil were $3.8 \%, 20.8 \%, 1.65 \%$, and $0.79 \%$, respectively. On the other hand, Akgören Palabıyık and Aytaç (2018) reported that black cumin oil contained thymoquinone by $67.7 \%$ as essential oil components, followed by carvacrol by $8.4 \%$, and junipene by $4.8 \%$. In our study, the main component of black cumin essential oil was thymoquinone by $45.41 \%$. The fact that the main components of black cumin essential oil were different from some studies may also be due to different climatic characteristics along with the different genotypic features of the plant material used. Namely, the fact that the temperature is high but the amount of precipitation is low especially in May and June (Table 1) was considered to lead to a high amount of thymoquinone. A similar situation was also indicated by Akgören Palabıyık and Aytaç (2018), and Herlina et al. (2017) reported that high temperature had an effect on high thymoquinone content.

\section{Conclusions}

According to the results of this study carried out under semi-arid climatic conditions, the applications of leonardite, known as a soil conditioner, and nitrogen fertilizer doses significantly affected the seed yield and yield components of black cumin. The highest seed yield was obtained from $2000 \mathrm{~kg} \mathrm{ha}^{-1}$ leonardite and $60 \mathrm{~kg} \mathrm{ha}^{-1}$ nitrogen applications. If some amount is waived in terms of essential oil and components of essential oil, the $\mathrm{L}_{2} \mathrm{~N}_{60}$ application can be recommended with respect to yield and quality.

\section{REFERENCES}

[1] Adiloğlu, A., Bellitürk, K., Adiloğlu, S., Solmaz, Y. (2017): The effect of increasing leonardit and farmyard manure applications on dry matter yield and some nutrient elements contents of rye (Secale cerale L.) plant. - Namık Kemal University, Scientific Research Project, Finally Report (No: NKUBAP. 03.GA.16.075), Tekirdağ, Turkey. (In Turkish).

[2] Ahmad, T., Khan, R., Khattak, T. N. (2018): Effect of humic acid and fulvic acid based liquid and foliar fertilizers on the yield of wheat crop. - Journal of Plant Nutrition 41(1): $1-8$.

[3] Akgören Palabıyık, G., Aytaç, Z. (2018): Chemical composition of the fixed and essential oils of Nigella sativa L. from Turkey. - Current Perspectives on Medicinal \& Aromatic Plants 1: 1927.

[4] Akgül, A. (1993): Spice Science and Technology. - Food Technology Association Publications No: 15. Ankara. pp. 72-74.

[5] Akınc1, Ş. (2011): Humic acids, plant growth and nutrient uptake. - International Journal of Advances in Engineering and Pure Sciences 23(1): 46-56. (In Turkish). 
[6] Anonymous (2018): Data from the General Directorate of Meteorology.

[7] Arslan, Y., Katar, D., Subaş1, İ. (2011): Effects of different sowing times on yield and some plant characteristics in black cumin (Nigella sativa L.). - Tibbi ve Aromatik Bitkiler Sempozyumu, 13-15 September, Gaziosmanpaşa University Agricultural Faculty. Tokat, Turkey. (In Turkish).

[8] Ashraf, M., Ali, Q., Iqbal, Z. (2006): Effect of nitrogen application rate on the content composition of oil, essential oil and minerals in black cumin (Nigella sativa L.) seeds. Journal of the Science of Food and Agriculture 86: 871-876.

[9] Başalma, D. (1999): The effect of nitrogen fertilization on yield and yield components of rape seed. - Journal of Central Research Institute for Field Crops 8: 12. (In Turkish).

[10] Baydar, H. (2013): Medical and Aromatic Plants Science and Technology. - Isparta, Turkey. (In Turkish).

[11] Calvo, P., Nelson, L. (2014): Kloepper, J.W. Agricultural uses of plant biostimulants. Plant and Soil 383(1): 3-41.

[12] Çöl, N., Akınerdem, F. (2017): The effect of humic acid applications in different quantities on the yield and some yield components on potato plant (Solanum tuberosum L.). - Selcuk Journal of Agriculture and Food Sciences 31(3): 24-32. (In Turkish).

[13] Dessie, A. B., Abate, T. M., Adane, B. T., Tesfa, T., Getu, S. (2020): Estimation of technical efficiency of black cumin (Nigella sativa L.) farming in northwest Ethiopia: a stochastic frontier approach. - Journal of Economic Structures 9(1): doi:10.1186/s40008020-00198-1.

[14] Eleroğlu, H., Korkmaz, K. (2016): Effects of different organic fertilizers on the yield and quality traits of seed potato cultivars (Solanum tuberosum L.). - Turkish Journal of Agriculture-Food Science and Technology 4(7): 566-578. (In Turkish).

[15] Ertaş, M. E. (2016): Determination of agronomic and quality properties in black cumin (Nigella sp.) genotypes sown in winter and spring periods. - Master's Thesis, Gaziosmanpaşa University Graduate School of Natural and Applied Sciences Department of Field Crops. Tokat. Turkey. 49p. (In Turkish).

[16] Esendal, E., Kevseroglu, K., Aytaç, S., Özyazıcı, G. (2000): Effects of different levels of nitrogen on some characters of datura collected from Samsun environs. - Turk J Agric For. 24: 333-339.

[17] Esringü, A., Sezen, I., Aytatl1, B., Ercişli, S. (2015): Effect of humic and fulvic acid application on growth parameters in Impatiens walleriana L. - Academic Journal of Agriculture 4(1): 37-42.

[18] Eyheraguibel, B., Silvestre, J., Morard, P. (2008): Effects of humic substances derived from organic waste enhancement on the growth and mineral nutrition of maize. Bioresource Technology 99: 4206.

[19] Gürsoy, M., Nofouzi, F., Başalma, D. (2016): Effects humic acid application at different stages of growth on yield and yield components of winter rapeseed crops. - Journal of Central Research Institute for Field Crops 25 (Special Number - 2): 131-136. (In Turkish).

[20] Gürsoy, M., Kolsarıc1, Ö. (2017): The effects of different humic acid dose on the yield and yield components of summer rape (Brassica napus ssp. oleifera L.) under Ankara conditions. - KSU J. Nat. Sci. 20 (Special Number): 186-191. (In Turkish).

[21] Harzallah, H. J., Kouidhi, B., Flamini, G., Bakhrouf, A., Mahjoub, T. (2011): Chemical composition, antimicrobial potential against cariogenic bacteria and cytotoxic activity of Tunisian Nigella sativa essential oil and thymoquinone. - Food Chemistry 129: 14691474.

[22] Herlina, N., Aziz, S. A., Kurniawati, A., Faridah, D. N. (2017): Changes of thymoquinone, thymol, and malondialdehyde content of black cumin (Nigella sativa $\mathrm{L}$.) in response to Indonesia tropical altitude variation. - HAYATI Journal of Biosciences 24: $156-161$. 
[23] Kalçın, F. T. (2003): Effect of plant density on yield and yield compenents on two black cumin species (Nigella sativa L, Nigella damascena L.). - Master Thesis, Ankara University, Graduate School of Natural and Applied Sciences, Department of Field Crops, Ankara, Turkey. 32p. (In Turkish).

[24] Karaca, E., Aytaç, S. (2007): The factors affecting on fatty acid composition of oil crops. - J. of Fac. of Agric. 22(1): 123-131. (In Turkish).

[25] Katar, D., Arslan, Y., Subaş1, İ. (2012): Effect of different doses of nitrogen on the yield and yield components of safflower (Carthamus tinctorius L.) under Ankara ecological conditions. - Süleyman Demirel University Journal of The Faculty of Agriculture 7(2): 56-64. (In Turkish).

[26] Khaled, H., Fawy, H. A. (2011): Effect of different levels of humic acids on the nutrient content, plant growth, and soil properties under conditions of salinity. - Soil \& Water Res. 6(1): 21-29.

[27] K1lıç, C., Arabacı, O. (2016): The effect of different sowing times and seed rate on the yield and quality of black cumin (Nigella sativa L.). - Journal of Adnan Menderes University Agricultural Faculty 13(2): 49-56.

[28] Kizılyıldırım, H. (2019): The effect of different nitrogen dosage applications on the yield and quality of black cumin (Nigella sativa) in Kahramanmaras ecological conditions. M.Sc. Thesis, Kahramanmaraş Sütçü İmam University Institute for Graduate Studies in Science and Technology Department of Field Crops. Kahramanmaraş, Turkey, 48p. (In Turkish).

[29] Kolay, B., Gürsoy, S., Avşar, Ö., Bayram, N., Öztürkmen, A. R., Aydemir, S., Aktaş, H. (2016): The effect of different levels of leonardite on wheat yield, yield components and some quality properties. - DUFED 5(3): 93-98. (In Turkish).

[30] Küçükemre, D. (2009): Effects of different row spacing and seeding rates on yield and some quality properties of black cumin (Nigella sativa L.). - Master Thesis, Gaziosmanpaşa University, Graduate School of Natural and Applied Sciences, Tokat, Turkey. 67p. (In Turkish).

[31] Kulan, E. G., Turan, Y. S., Gülmezoğlu, N., Kara, İ., Aytaç, Z. (2011): Some agronomic and quality properties of black cumin (Nigella sativa L.) cultivated under dry conditions. - Tibbi ve Aromatik Bitkiler Sempozyumu. 13-15 September. Gaziosmanpaşa University Faculty of Agriculture. Tokat, Turkey. (In Turkish).

[32] Larcher, W. (2003): Physiological Plant Ecology: Ecophysiology and Stress Physiology of Functional Groups. - 4th. Edition. Springer. New York. 513p.

[33] Laz, O. (2011): Effects of soil improver polymer (PVA, PAM \& HJ) and humic acid applications on some soil properties and plant growth. - Master Thesis, Atatürk University, Graduate School of Natural and Applied Sciences. Erzurum, Turkey, 79p. (In Turkish).

[34] Li, Y., Fang, F., Wei, J., Wu, X., Cui, R., Li, G., Zheng, F., Tan, D. (2019): Humic acid fertilizer improved soil properties and soil microbial diversity of continuous cropping peanut: a three-year experiment. - Scientific Reports 9: 12014.

[35] Mackowiak, C. L., Grossl, P. R., Bugbee, B. G. (2001): Beneficial effects of humic acid on micronutrient availability to wheat. - Soil Science Society of America Journal 56: 1744-1750.

[36] Mollafilabi, A., Moodi, H., Rashed, M. H., Kafi, M. (2010): Effect of plant density and nitrogen on yield and yield components of black cumin (Nigella sativa L.). - Acta Horticulturae 853: 115-126.

[37] Moretti, A., D'Antuono, L. F., Elementi, S. (2004): Essential oils of Nigella sativa L. and Nigella damascena L. seed. - Journal of Essential Oil Research 16(3): 182-183.

[38] Muhammad, A. G., Ahmad, R. M., Muhammad, K. E. (2017): Response of growth, yield and oil content of two black seed species to nitrogen fertilizer in Sulaimani District. Euphrates Journal of Agriculture Science 9(4): 18-52. 


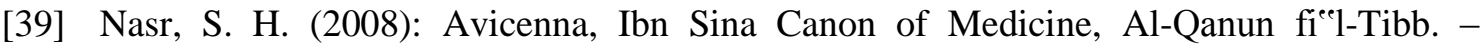
Volume 1. USA: Great Books of the Islamic World, Kazi Publications.

[40] Orchid, H., Nmila, R., Bessière, J. M. R., Sauvaire, Y. (2004): Volatile components of Nigella damascena L. and Nigella sativa L. seeds. - Journal of Essential Oil Research 16(6): 585-587.

[41] Özgüven, M., Şekeroglu, N. (2007): Agricultural practies for high yield and quality of black cumin (Nigella sativa L.) cultivated in Turkey. - Acta Hotriculturae 756: 329-337.

[42] Özyazıcı, G., Özdemir, O., Özyazıcı, M. A., Üstün, G. Y., Turan, A. (2010): The effects of organic materials and soil regulators in organic hazelnut production on yield and some soil properties. - IV. Organic Agriculture Symposium, 28 June-1 July. Erzurum. (In Turkish).

[43] Pekcan, T., Çolak Esetlili, B., Turan, H. S., Aydoğdu, E. (2018): Determination of some physical and chemical properties of organic materials originated from leonardite. Journal of Agricultural Faculty of Uludag University 32(1): 31-41. (In Turkish).

[44] Rana, S., Singh, P. P., Naruka, I. S., Rathore, S. S. (2012): Effect of nitrogen and phosphoruson growth, yield and quality of black cumin (Nigella sativa L.). International Journal of Seed Spices 2(2): 5-8.

[45] Sağlam, T. (2018): Effect of nitrogen and potassium application on yield and quality of black cumin (Nigella sativa L.). - Master Thesis, Eskişehir Osmangazi University, Graduate School of Natural and Applied Sciences, Department of Field Crops, Eskişehir, Turkey, 60p. (In Turkish).

[46] Selicioğlu, M. (2018): Determination of agronomical and quality characters of some black cumin (Nigella sp.) populations in Kırşehir ecological conditions. - M.Sc. Thesis, Süleyman Demirel University Graduate School of Natural and Applied Sciences Department of Field Crops, Isparta, Turkey, 36p. (In Turkish).

[47] Selladurai, R., Purakayastha, T. J. (2016): Effect of humic acid multinutrient fertilizers on yield and nutrient use efficiency of potato. - Journal of Plant Nutrition 39: 949-956.

[48] Sesveren, S., Taş, B. (2018): The effects on water consumption and some growth parameters of different level of leonardite in curly leaf salad (Lactuva sativa var. crispa). - Turkish Journal of Agriculture-Food Science and Technology 6(4): 421-426. (In Turkish)

[49] Seyyedi, M. S., Moghaddam, P., Hosseini, M. K., Shahandeh, H. (2015): Influence of phosphorus and soil amendments on black seed (Nigella sativa L.) oil yield and nutrient uptake. - Industrial Crops and Products 77: 167-174.

[50] Shah, S. H. (2004): Morphophysiological response of black cumin (Nigella sativa L.) to nitrogen, gibberellic acid and kinetin application. - Ph.D Thesis, Aligarh Muslim University Aligarh, India.

[51] Sharif, M., Khattak, R. A., Sarir, M. S. (2002): Effect of different levels of lignitic coal derived humic acid on growth of maize plants. - Soil Science and Plant Analysis 33(1920): 3567-3580.

[52] Stevenson, F. J. (1994): Humus Chemistry: Genesis, Composition, Reactions. - 2nd. Edition, John Wiley and Sons. Inc. New York. 285p.

[53] Sultana, S., Mondal, A., Das, S., Rudra, B. C., Alam, B., Roy, S. (2019): Effect of nitrogen and phosphorous fertilizer application on growth and yield of black cumin cultivation in Malda District (WB). - Int. J. Curr. Microbiol. App. Sci. 8(04): 2813-2817.

[54] Şanl, A., Karadoğan, T. (2011): Effects of leonardite applications on the yield and quality properties of some potato (Solanum tuberosum L.) varieties. - Turkey IX. Field Crops Conference, Industrial Plants and Biotechnology, 12-15 September, Bursa,Turkey, pp. 1085-1088. (In Turkish).

[55] Şanlı, A., Karadoğan, T., Tonguç, M. (2013): Effects of leonardite applications on yield and some quality parameters of potatoes (Solanum tuberosum L.). - Turkish Journal of Field Crops 18(1): 20-26. 
[56] Toma, C., Simu, G. M., Olah, N., Georgiana, F. M., Hammami, C., Hammami, M. (2010): Chemical composition of the Tunisian Nigella sativa. Note I. profile on essential oil. - Farmacia 58: 458-464.

[57] Tunçtürk, R., Tunçtürk, M., Türközü, D. (2011): The effects of different phosphorous and nitrogen doses on the yield and quality of fennel (Foeniculum vulgare Mill.) in Van ecological conditions. - YYU J Agr Sci. 21(1): 19-27. (In Turkish).

[58] Tuncturk, R., Tuncturk, M., Ciftci, V. (2012): The effects of varying nitrogen doses on yield and some yield components of black cumin (Nigella sativa L.). - Advances in Environmental Biology 6(2): 855-858.

[59] Türker, L., Bayrak, A. (1997): An investigation of the fixed and essential oil composition of black cumin (Nigella sativa L.). - Standard, pp. 128-197.

[60] Türközü, D. (2005): Effects of different nitrogen doses and sowing times on yield and yield components and quality in black cumin (Nigella sativa) under Van ecological conditions. - M.Sc. Thesis, Yüzüncü Yıl University Graduate School of Natural and Applied Sciences, Van, Turkey. (In Turkish).

[61] Wadas, W., Dziugiel, T. (2019): Growth and marketable potato (Solanum tuberosum L.) tuber yield in response to foliar application of seaweed extract and humic acids. Applied Ecology and Environmental Research 17(6): 13219-13230.

[62] Yağmur, B., Okur, B. (2017): The effect of humic acid and potassium applications on growth of oil seed sunflower (Helianthus annuus L.). - Turkish Journal of Agricultural Research 4(3): 210-217.

[63] Yildırım, N., Kan, Y. (2006): Effect of different nitrogen and zinc doses on yield and yield components of fennel (Foeniculum vulgare Mill. var. dulce). - Selcuk Journal of Agriculture and Food Sciences 20(40): 94-101. (In Turkish).

[64] Yilmaz, C. (2007): Humic and Fulvic Acid. - Harvest Plant Production Journal 260: 74. (In Turkish).

[65] Yimam, E., Nebiyu, A., Mohammed, A., Getachew, M. (2015): Effect of nitrogen and phosphorus fertilizers on growth, yield and yield components of black cumin (Nigella sativa) at Konta district South West Ethiopia. - Department of Horticulture Plant Science, College of Agriculture and Veterinary Medicine, Jimma University, Ethiopia.

[66] Yüksek, T., Çilli, M., Kılınç, E., Yüksek, F. (2016): Changes in essential oil content tea seed and leaves according to the elevation and soil characteristics. - Journal of Anatolian Environmental \& Animal Sciences 1(1): 28-33. (In Turkish).

[67] Yurtsever, N. (1984): Experimental Statistical Methods. Ministry of Agriculture, Forestry and Rural Affairs. - General Directorate of Rural Services Publication, No. 623. (In Turkish). 